


\title{
Who is a Passive Saver Under Opt-In and Auto-Enrollment?*
}

\author{
Gopi Shah Goda ${ }^{\dagger}$ Matthew R. Levy ${ }^{\ddagger}$ Colleen Flaherty Manchester ${ }^{\S}$ \\ Aaron Sojourner "Joshua Tasoff"
}

July 18, 2019

\begin{abstract}
Defaults have been shown to have a powerful effect on retirement saving behavior yet there is limited research on who is most affected by defaults and whether this varies based on features of the choice environment. Using administrative data on employer-sponsored retirement accounts linked to survey data, we estimate the relationship between retirement saving choices and individual characteristics - long-term discounting, present bias, financial literacy, and exponentialgrowth bias - under two distinct choice environments: an opt-in regime and an auto-enrollment regime. Consistent with our conceptual model, we find that the determinants of following the default and contribution behavior are regime-specific. Under the opt-in regime, financial literacy plays an important role in predicting total contributions, active saving choices, and maxing out contributions in the tax-preferred account. In contrast, under the auto-enrollment regime, present bias is the most significant behavioral predictor of contribution behavior. A causal interpretation of the estimates suggests that auto-enrollment increases saving primarily among those with low financial literacy.
\end{abstract}

Keywords: present bias; exponential-growth bias; household finance; retirement saving decisions; choice architecture; defaults; financial literacy; procrastination.

\footnotetext{
*Acknowledgments: This research was supported by the U.S. Social Security Administration through grant \#RRC08098400-09 to the National Bureau of Economic Research (NBER) as part of the SSA Retirement Research Consortium, by the TIAA Institute through grant \#124652, and the Laura and John Arnold Foundation through a grant to the Stanford Institute for Economic Policy Research (SIEPR). The findings and conclusions expressed are solely those of the authors and do not represent the views of SSA, any agency of the Federal Government, the NBER, TIAA/TIAA Institute, the Laura and John Arnold Foundation, SIEPR or any other institution with which the authors are affiliated. We are grateful to Paula Gablenz and Konhee Chang for exceptional research assistance. (C) 2017 Goda, Levy, Manchester, Sojourner and Tasoff. All rights reserved.

${ }^{\dagger}$ Stanford University, 366 Galvez Street, Stanford, CA 94305. gopi@stanford.edu

${ }^{\ddagger}$ London School of Economics, Houghton Street, London WC2A 2AE, UK. m.r.levy@lse.ac.uk

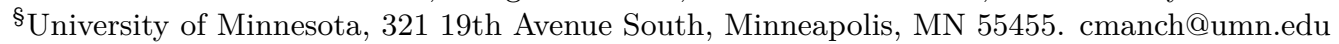

`University of Minnesota, 321 19th Avenue South, Minneapolis, MN 55455. asojourn@umn.edu

"Claremont Graduate University, 160 East Tenth St, Claremont CA, 91711. joshua.tasoff@cgu.edu
} 


\section{Introduction}

Starting with the work of Madrian and Shea (2001), a substantial body of research on retirement plans has shown that defaults, which specify the outcome that occurs when no active choice is made, have strong effects on the saving behavior of individuals (Choi et al., 2004; Beshears et al., 2009; Goda and Manchester, 2013). Understanding the powerful effects of defaults on saving behavior remains an important area of examination given their widespread use in retirement savings plans and scope for policymakers to regulate the defaults set by plan sponsors. Recent theoretical work has provided many potential explanations for the powerful effects of defaults on saving outcomes. These explanations include inertia, including that induced by present-biased preferences, choice overload, or transaction costs; by endorsement whereby individuals trust that the plan provider selected a "good" default; or by framing such that individuals judge losses and gains against the default (Tversky and Kahneman, 1975; Iyengar and Lepper, 2000; O’Donoghue and Rabin, 1999a,b, 2001; Ariely et al., 2003; Carroll et al., 2009; Sunstein, 2017; Butt et al., 2018). While these arguments are compelling, why defaults work and for whom are they most influential is ultimately an empirical question.

A key aspect of understanding why defaults have powerful effects is whether an individual's tendency to follow the default is a stable, individual attribute, or whether it varies based on features of the choice environment (e.g., framing, the specified default, etc.) On the one hand, recent research suggests that the tendency to be passive (i.e. follow the default) is an individuallevel attribute. Namely, Chetty et al. (2014) examine individual's response to changes in default saving rates and saving subsidies using Danish data, finding evidence that the vast majority of individuals are passive (i.e., follow automatic contribution rates and do not respond to subsidies). They find evidence that those who offset changes in automatic contribution rates and respond actively to subsidies were more likely to have made changes to contributions in the past and are "wealthier, older, or have economics training" (p. 1145). They conclude that passive individuals are less financially-sophisticated than active individuals and frame passive versus active as an individual attribute. A prediction of a passive-as-type theory is a stable joint distribution between individual characteristics like wealth, age, and education and the propensity to make active saving choices across multiple time periods. On the other hand, recent evidence suggests that following the 
default may not be a stable individual-level attribute. Findings from Butt et al. (2018) show that while $37 \%$ of individuals are passive in two distinct retirement plan decisions (i.e., selection of the plan and selection of asset allocation) in the public, defined contribution (DC) plan in Australia, $36 \%$ are passive in one choice, but active in the other. Further, Van Rooij and Teppa (2014) find evidence that the predictors of default behavior vary based on whether the choice is economic (i.e., contributing to a supplemental retirement account) as opposed to non-economic (i.e., organ donation).

This paper examines whether the predictors of retirement contribution behavior vary based on aspects of the choice environment, namely the default contribution rate. We consider how known drivers of saving behavior - long-term discount rate, present bias, exponential-growth bias, and financial literacy - may differently influence contribution behavior across two distinct default regimes: opt-in versus automatic enrollment. We present a conceptual framework and empirical evaluation using a setting that changed from an opt-in regime (i.e., $0 \%$ default contribution rate) to an auto-enrollment regime with a $3 \%$ default contribution rate.

Our approach combines administrative records on employee contribution elections from an employer-provided retirement savings plan with direct, survey elicitations of long-term discount rate, present bias, exponential-growth bias, and financial literacy. Present-bias refers to the preference to overweight immediate benefits and costs relative to future benefits and costs. It has been posited as a driver of default behavior for several decades (O’Donoghue and Rabin, 1999b) but little direct evidence has connected individual measures of present bias to default acceptance (Brown and Previtero, 2014) and no prior evidence has looked at it across different default regimes. Exponentialgrowth bias is the tendency to underestimate the effect of compounding interest (Stango and Zinman, 2009), and recent research has shown that it is associated with retirement savings (Goda et al., 2019). Financial literacy has been shown to play an important role in various savings behaviors (see for example Lusardi and Mitchell, 2007). We evaluate how these measures predict six retirement contribution behaviors: following the default contribution rate, one's annual contribution amount and annual contribution rate, making any contribution, contributing to maximize the employer match, and contributing the annual allowable maximum for tax-preferred saving. Our data come from employees at the U.S. Office of Personnel Management (OPM), an agency that provides human resources, leadership, and support to most federal agencies. We analyze choices 
pertaining to the Thrift Savings Plan (TSP), a tax-advantaged DC plan for Federal employees that provides retirement income in addition to a defined benefit pension, controlling for a rich set of covariates relevant to contribution decisions, including salary, demographics and education.

We find evidence that the relative influence of individual-level attributes in predicting saving behavior varies significantly across the two default regimes. We find that our measure of present-biased preferences is a significant determinant of following the default rate in the automatic enrollment regime, indicating that higher levels of present bias are associated with higher probabilities of sticking to the default. By contrast, present bias does not predict the tendency to follow the default in the opt-in regime and this difference in the predicted effect is statistically different across the default regimes. In addition, we also find that our financial literacy measure has a statistically significant positive relationship with annual TSP contribution amounts (and rates) and the likelihood of making a positive contribution election in the opt-in regime. Yet in the automatic enrollment regime, not only are these effects absent, the difference in the predicted relationship between financial literacy and these saving outcomes is statistically different across regimes. A causal interpretation of the estimates suggests that auto-enrollment increases retirement contribution primarily among those with low financial literacy.

We contribute to the literature on the effects of defaults on saving outcomes by showing evidence that features of the choice environment, namely the default rate set by a plan, influences which individual-level attitudes manifest as relevant for determining saving behavior. We also provide empirical evidence that directly supports a key prediction of Carroll et al. (2009) in terms of presentbiased preferences and default rate by finding higher rates of staying with the default when the rate is likely to be closer to the optimal contribution rate (i.e., $3 \%$ versus $0 \%$ ). Yet our conceptual framework extends beyond that of Carroll et al. (2009) by considering how the influence of other known factors relevant to saving behavior, such as financial literacy and exponential-growth bias, may vary based on the default rate set by a plan. A key insight from our model is that the default rate set by the plan may send a stronger signal about optimal saving behavior for those with lower levels of financial literacy relative to those with higher levels particularly when the rate is farther from one's priors, which provides a novel angle on the literature's understanding of the endorsement effect of defaults.

We also contribute to the literature on determinants of saving by showing that the relevance of 
well-studied predictors of savings and saving behavior depends on features of the choice environment. Prior work on the role of financial literacy (Lusardi and Mitchell, 2007; Hung et al., 2009; Lusardi and Mitchell, 2011; Ameriks et al., 2003), time preferences (Heutel et al., 2014; Brown and Previtero, 2014), and exponential-growth bias (Stango and Zinman, 2009; Levy and Tasoff, 2016) as predictors of saving behavior as well as studies that use measures of several of these factors as predictors (Stango et al., 2017; Goda et al., 2019) typically fail to take into account aspects of the choice environment in their approach or in understanding their findings. Our findings suggest that aspects of the choice environments, namely the default contribution rate set by the plan, is an important boundary condition for understanding the relationship between these predictors and saving outcomes.

The remainder of this paper is organized as follows. In Section 2 we provide a framework for how the default rate set by the plan may affect the role of present-biased preferences, exponentialgrowth bias, and financial literacy in determining active versus passive choice as well as contribution decisions. In Section 3, we describe the context and our sources of data, including administrative records and linked survey responses. Section 4 presents our results and their robustness to various assumptions and Section 5 discusses them. Section 6 concludes.

\section{Conceptual Framework}

In this section, we briefly introduce a conceptual framework in order to clarify both how individual characteristics - long-term discounting, present bias, exponential-growth bias, financial literacy are predicted to affect different margins of behavior, as well as why these four behavioral measures in particular were chosen for inclusion. We consider the retirement savings contribution decision of an agent who first observes a default contribution rate and then decides whether to change their contribution from this rate and, if so, to what. The default rate, $d$, is set by the agent's employer. The default contribution rate may differ from the agent's optimal contribution rate, $s^{*}$, which is determined by some other (unmodeled) optimization.

We extend the framework of Carroll et al. (2009) to allow agents to be uncertain over the optimal contribution rate. Agents are endowed with prior beliefs over $s^{*}$ given by $F(\cdot)$. For simplicity, we assume $F$ is single-peaked and continuously distributed over $[0,1]$. The employer's choice of the 
default contribution rate $d$ as a function of an agent's optimal contribution rate can provide the agent with a signal of $s^{*}$ (McKenzie et al., 2006). The signal is distributed according to $G\left(\cdot \mid s^{*}\right)$. The family of distributions $G\left(\cdot \mid s^{*}\right)$ are assumed to (weakly) satisfy a monotone likelihood ratio property, such that higher defaults are (weakly) more likely given higher optimal savings rates. This condition is stated weakly, as it may be that the default is independent of $s^{*}$ if employers chose it for reasons unrelated to the well-being of their employees (e.g., legal concerns).

The agent experiences a loss from saving at a rate $s$ different from $s^{*}$ denoted by $L\left(s, s^{*}\right)$. We assume that $L$ is strictly concave in its first argument, and that it attains a maximum value of zero along the line $s=s^{*}$. Furthermore, we assume that the opt-in regime $(d=0 \%)$ is "worse" than auto-enrollment regime ( $d=3 \%$, as in the setting we will study) in the following ex-ante sense:

$$
E_{F}\left[L\left(0 \%, s^{*}\right)\right]<E_{F}\left[L\left(3 \%, s^{*}\right)\right]
$$

The agent may change their contribution rate by paying a transaction cost $c$, capturing both the time and effort of making a change. If the agent does not make a change, their expected utility is:

$$
\mathrm{EU}(d)=E_{F}\left[L\left(d, s^{*}\right) \mid d\right]
$$

Conditional on making a change, the optimal change would be to a value $s^{* *}$ that maximizes expected utility. Without additional structure on $L$, this will of course not generally be equal to $s^{*}$ as the costs of over-saving may be asymmetric to the costs of under-saving. Given the linearity of the expectations operator and concavity of $L$ given any $s^{*}$, however, there will generically exist a unique value which solves

$$
s^{* *}=\arg \max _{s} E_{F}\left[L\left(s, s^{*}\right) \mid d\right]
$$

If the agent does make a change, then their expected utility is: $\operatorname{EU}\left(s^{* *}\right)=\max _{s} E_{F}\left[L\left(s, s^{*}\right) \mid d\right]$, which is the constrained maximum given their information.

\section{$2.1 \quad$ Predictions}

We now consider four dimensions of individual heterogeneity, which have been proposed as explanations for default effects in prior literature. The purpose of this subsection, however, is to 
demonstrate how they enter the agent's problem in differing ways and can be understood in conceptually distinct ways.

Long-Run Discounting $(\delta)$ : Exponential time discounting of additively separable preferences has a long and well-studied history in lifecycle consumption problems. In a discrete-time framework, agents discount the future by a constant factor $\delta \in[0,1]$. Agents who are more patient in the longrun (higher $\delta$ ) will perceive a higher savings rate to be desirable relative to those with lower values of $\delta$. We capture this notion by assuming that they have a prior distribution over $s^{*}$ which first-order stochastically dominates that of less-patient agents.

Because a greater level of patience shifts the prior distribution $F$ upwards, a higher $\delta$ should be associated with a higher contribution level for any default. It may also be associated with the probability of remaining at the default: in the opt-in regime, there should be a threshold $\delta$ above which the agent makes a change; conversely, under auto-enrollment there should be an interior interval of passive behavior as both upward and downward deviations are possible.

Present Bias $(\beta)$ : We assume that agents may also exhibit quasi-hyperbolic discounting in their time preferences (Phelps and Pollak, 1968; Laibson, 1997). Let $x \in \mathbb{R}^{T-t+1}$ be a vector of consumption then:

$$
U_{i, t}(x) \equiv u_{i}\left(x_{t}\right)+\beta_{i} \sum_{\tau=t+1}^{T} \delta_{i}^{\tau-t} u_{i}\left(x_{\tau}\right)
$$

where $T$ is the final period, $t$ is the current period, $i$ is the individual, $1-\beta_{i}$ is the degree of present bias, and $\delta_{i}$ is the (exponential) long-run discount factor. However, we abstract away from the additively separable consumption over time in the present conceptual framework. Because $\beta$ does not compound, we assume that it does not affect the perceived distribution of $s^{*}$, as $\delta$ does. Rather, present-bias is expected to distort the timing of decision to implement a change (O'Donoghue and Rabin, 2001).

In our framework, present-biased preferences may distort the decision of whether to make a change because the benefits of making a change to their contribution rate arise only in the future but the transaction costs arise in the period in which the change is made. We assume that the transaction cost $c$ is fixed and that the horizon is finite, so that the optimal strategy will be to make a change either immediately or never. With a non-constant schedule for $c$ or infinite horizon 
there may be other solutions which involve some degree of procrastination which we abstract from, but which have been studied elsewhere (Carroll et al., 2009).

We assume that any long-run discounting has already been included in $L$, in which case the agent will actually implement a choice whenever:

$$
\beta\left(E\left[L\left(s^{* *}, s^{*}\right) \mid d\right]-E\left[L\left(d, s^{*}\right) \mid d\right]\right) \geq c
$$

Ceteris paribus, more present-biased agents should be less likely to make a change regardless of the default. This is immediate upon inspection of inequality (5), as the left-hand side is clearly increasing in $\beta$. Less straightforwardly, inequality (5) may be satisfied by even low values of $\beta$ when the perceived benefit of switching from $d$ to $s^{* *}$ are sufficiently high. If agents are correctly computing the term in parentheses in equation (5), then for any default there will be a cutoff $\beta$ for making a change. For a sufficiently bad default, this cutoff may be below the minimum $\beta$ in the population, so most people will make a change and $\beta$ would not be a good predictor of this event. Improving the default makes variation in $\beta$ more relevant for making a change. This implies that the effect of present bias on staying at the default rate may be higher under the auto-enrollment $(d=3 \%)$ regime relative to the opt-in enrollment $(d=0 \%){ }^{1}$

Exponential-Growth Bias $(\alpha)$ : Exponential-growth bias is the tendency for individuals to partially linearize compound growth processes, thereby under-estimating the effect of compound interest (Stango and Zinman, 2009). We consider the parametric model of Levy and Tasoff (2016) for exposition. Let $\alpha_{i}$ represent individual $i$ 's accuracy in their exponential perceptions. Given an interest rate $\vec{r}$ and time horizon $T$, the person's perception function $p\left(\vec{r}, t ; \alpha_{i}\right)$ is the perception of the period- $T$ value of one dollar invested at time $t<T$ :

$$
p\left(\vec{r}, t ; \alpha_{i}\right)=\prod_{s=t}^{T-1}\left(1+\alpha_{i} r_{s}\right)+\sum_{s=t}^{T-1}\left(1-\alpha_{i}\right) r_{s}
$$

When $\alpha_{i}=0$, the individual perceives growth to be linear, fully neglecting compound interest. When $\alpha_{i}=1$, the person correctly perceives growth to be exponential. Values of $\alpha_{i} \in(0,1)$ generate perceptions that are in between linear and exponential growth. Values $>1$ reflect over-

\footnotetext{
${ }^{1}$ This prediction also appears in Carroll et al. (2009), albeit in a repeated decision with stochastic cost realizations.
} 
estimation of the returns to compounding.

This mis-perception causes agents to under-estimate the returns to savings, and potentially induces both an income and a substitution effect (Levy and Tasoff, 2016). The effect on the perceived optimal contribution rate is therefore ambiguous. However, because agents systematically under-estimate the sensitivity of their retirement savings balances to their saving rate, we can capture the effect of exponential-growth bias by assuming that $\left|\partial L\left(s, s^{*}\right) / \partial s\right|$ is decreasing in the degree of exponential-growth bias. That is, exponential-growth bias depresses the perceived link between savings behaviors and savings outcomes, and therefore more-biased agents believe that a larger change in the savings rate is required to induce a given change in utility. We therefore predict that more biased agents should be more likely to remain at the default in both regimes, as equation (5) is less likely to be satisfied. Conditional on making an active choice, the effect on savings rates is potentially ambiguous, as we have not imposed restrictions on how exponential-growth bias affects the perceived loss from too-high savings relative to too-low.

Financial Literacy: Financial literacy is slightly more nebulous than the previous three measures, but is generally understood that advanced financial knowledge (for example, risk diversification) and the capacity to do financial calculations are central to the concept (Lusardi and Mitchell, 2011, 2014). A highly financially literate person should therefore be expected to be able to use all available information to formulate and execute a retirement savings plan. Conversely, a financially illiterate agent may find the decision quite baffling and may rely on the implicit recommendation of the employer's default choice for guidance. ${ }^{2}$ We assume that the perceived precision of this signal is (weakly) decreasing in financial literacy, in the sense of second-order stochastic dominance. It will be more convenient (though equivalent, given the generality of the model), to treat financial literacy as affecting the signal rather than the prior.

Agents with lower degrees of financial literacy thus interpret the default as a stronger signal regarding $s^{*}$. Their posterior beliefs, given by $f\left(s^{*} \mid d\right) \equiv f\left(s^{*}\right) g\left(d \mid s^{*}\right) / \int g(d \mid s) d F(s)$, have a density strictly higher at points near the default and strictly lower at points distant than agents with higher degrees of financial literacy. If the default is close to the prior $F$, then the default will not induce a large change in beliefs for any degree of financial literacy. As we find it likely that the prior places

\footnotetext{
${ }^{2}$ Sunstein (2017) notes that given, "the informational signal that the default rule provides... people may not want to [depart from it] unless they are quite confident."
} 
a greater density near a $3 \%$ savings rate than a $0 \%$ rate, we predict that financial literacy should have a greater impact on both remaining at the default and on contribution rates under the opt-in regime than under the auto-enrollment regime.

\section{Setting and Data}

\subsection{Retirement Plan Setting}

Benefits-covered federal employees participate in a supplemental defined contribution (DC) plan, the Thrift Savings Plan (TSP), in addition to a mandatory defined benefit (DB) plan. Employees receive a base TSP contribution of 1 percent from the agency and a further match on employee contributions up to 5 percent of pay. The agency matches dollar-for-dollar on an employee's contributions up to 3 percent of pay and $\$ 0.50$ on the dollar for the next two percent of pay. Employees can contribute up to the IRS maximum each year, which was $\$ 18,000$ in $2017 .^{3}$ Employees may elect to invest their contributions in five different funds or a lifecycle option, which is a mix of the other funds based on the employee's age.

The federal government implemented automatic enrollment for all covered employees hired after August 1, 2010. Before this, employees were required to opt in to participate in TSP. After autoenrollment started, employees were enrolled in TSP at a 3 percent contribution rate unless they opted out. Therefore, the default contribution rate is zero for those hired prior to August 1, 2010 and 3 percent for those hired later.

Our administrative data combine TSP contribution elections with HR records. These data were collected as of April 2017, and include 5,472 employees. All outcomes we examine derive from this TSP retirement contributions cross-section. We fielded an online survey between March 29, 2017 to April 14, 2017 to these employees, and 1,585 (29\%) provided complete response on the variables of interest. ${ }^{4}$ Our survey included one initial invitation and two reminders sent via email. We use

\footnotetext{
${ }^{3}$ Employees hired before 1984 are covered by a more comprehensive DB plan and receive no base and no match on employee contributions to TSP, although they are allowed to contribute up to the IRS maximum allowable each year. Fewer than 10 percent of the current full-time, non-seasonal Federal employees are in this more comprehensive plan.

${ }^{4}$ Survey respondents differ on average from non-respondents in terms of TSP contribution decisions as well as some covariates given survey respondents are more attentive and engaged employees. However, selection into survey response based on TSP outcomes and covariates does not differ between TSP default regimes at the time of hire, mitigating concern that differential selection into the survey sample between regimes drives results.
} 
this survey to elicit the long-term discount rate, present-biased preferences, exponential-growth bias and measures of financial literacy. Our sample includes 1,396 of the 1,585 survey responders who answered key questions in our survey required for analysis. Below we describe the outcome variables, elicitation of behavioral measures, and control variables.

\subsection{Outcome variables}

We construct each employee's annual TSP contribution amount using data on contribution elections while taking into account the maximum allowable annual contribution of $\$ 18,000 .^{5}$ We report contributions both as an annual dollar amount and as a percent of salary. We construct additional measures of contribution choices including binary indicators of whether the employee passively enrolled, whether the employee's saving choice is consistent with the default in place at the time of hire, whether the employee contributes an amount that maximizes their match from the Federal government, whether the employee contributes the annual maximum, and whether the employee contributes to TSP at all. The binary indicator describing whether the employee made a passive choice is only present for employees hired after auto-enrollment was instituted ${ }^{6}$ the data do not distinguish between passive and active non-participants hired in the earlier, opt-in regime. Whether an employee's contribution choice is consistent with the default is available for both regimes, yet differs from the passive measure in the automatic enrollment regime due to some employees actively electing a $3 \%$ contribution rate.

\footnotetext{
${ }^{5}$ Employees can elect DC contributions as a percent of pay, or as a dollar amount per pay period.

${ }^{6}$ The measure in the data indicating passive enrollment is missing for 10 individuals, leaving 651 for analysis using this variable instead of 661 for the auto-enrollment cohort.
} 
Table 1: Summary Statistics - Outcome Variables

\begin{tabular}{lcc}
\hline \hline & Opt-In Regime & Auto-Enroll Regime \\
\hline TSP Amount (\$/year) & 8699.480 & 5160.133 \\
& $(6418.502)$ & $(4987.889)$ \\
TSP Rate & 8.692 & 6.600 \\
& $(6.005)$ & $(5.045)$ \\
Passive & & 0.118 \\
& & $(0.323)$ \\
At Default & 0.088 & 0.147 \\
& $(0.284)$ & $(0.354)$ \\
At/Above Max. Match & 0.614 & 0.576 \\
& $(0.487)$ & $(0.495)$ \\
At 0\% & 0.088 & 0.048 \\
& $(0.284)$ & $(0.215)$ \\
At Cap & 0.131 & 0.042 \\
Total Pay (\$/year) & $(0.337)$ & $(0.202)$ \\
& 98456.467 & 73073.817 \\
Observations & $(26404.520)$ & $(32918.612)$ \\
\hline \hline
\end{tabular}

Notes: TSP Amount reflects annual Roth and Traditional TSP contributions

subject to annual maximum, including catch-up contributions if eligible. See

text for more details.

Table 1 presents summary statistics for our main outcome variables separately for employees who were hired before and after the introduction of automatic enrollment. Because auto-enrollment is determined by hire date, and our data come from a single cross-section, auto-enrollment is confounded with length of service and, to some extent, with age and career stage. Employees hired in the opt-in regime have annual TSP contributions of $\$ 8,699$ on average, while the younger cohort hired under auto-enrollment averages $\$ 5,160$. TSP contributions as a percent of salary are also higher for those hired under the opt-in regime.

Approximately 9 percent of opt-in regime employees are at their default contribution rate of 
0 percent, whereas only 4.8 percent of auto-enrolled employees do not participate. Instead, 14.7 percent of auto-enrolled employees are at the default contribution rate of 3 percent. Our data include an indicator of whether the employee made an election or was passively enrolled in the plan (for automatic enrollment regime). This variable indicates that the vast majority of those at the default contribution rate are there through passive enrollment: 11.8 percent of the sample, or 80 percent of those at the 3-percent default did not actively choose their contribution rate.

The two groups of employees also differ on their contributions at higher levels. Approximately 61 percent of employees hired under the opt-in regime contribute at least 5 percent of their salary, while 58 percent of auto-enrolled employees contribute at least 5 percent. Finally, we observe that whereas 13 percent of employees hired under the opt-in regime are contributing the annual maximum of $\$ 18,000$ per year, only 4.2 percent of auto-enrolled employees are at this cap.

\subsection{Time preferences}

We use a "time-staircase" procedure to construct a simple measure of present bias, which we refer to as "Beta", as well as of the long-run discount factor ("Delta") in an approach similar to Goda et al. (2019). The method was first devloped by Falk et al. (2016) for only measuring the long-run discount factor. The staircases have the form:

Present-Future Staircase: Would you rather receive $\$ 100$ today or $\$[X]$ in 12 months?

Future-Future Staircase: Would you rather receive $\$ 120$ in 12 months or $\$[Y]$ in 24 months?

Subjects begin with a common value of $[X]$ or $[Y]$. If a subject indicates they prefer the money sooner (later), then the second dollar amount increases (decreases) on the next question. ${ }^{7}$ For each staircase, subjects answer five questions, gradually narrowing the interval that contains the indifference point. Since the questions are binary and have parallel structure, they are easily understood and can be answered quickly. Participants were asked these questions for a 12-month (as shown above) and 6-month time interval, for a total of four sets. ${ }^{8}$ We randomize the order of the staircases and utilize different base values for the different sets of questions (i.e., the Present-Future Staircase always begins with $\$ 100$ today and the Future-Future Staircase with $\$ 120$ in 12 months) to minimize the influence of mechanical responses. While this staircase method did not involve

\footnotetext{
${ }^{7}$ In our survey instrument, the future value X was always greater than 100 and Y was always greater than 120.

${ }^{8}$ We collect multiple measures to address measurement error (see Section 4.2).
} 
real stakes, Falk et al. (2014) show that behavior between a no-stakes and real-stakes version is highly correlated. ${ }^{9}$ From these staircases we construct measures of Beta and Delta from the implied indifference point. ${ }^{10}$

\subsection{Exponential-growth bias}

We measure exponential-growth bias separately given that previous work has found that this bias is particularly important for retirement saving due to its long investment horizon (Stango and Zinman, 2009; Goda et al., 2019). To assess exponential-growth bias, we include three hypothetical investment questions asking participants to provide a value for an asset given a specified return and time horizon. An example question is, "An asset has an initial value of $\$ 100$ and grows at an interest rate of $10 \%$ each period. What is the value of the asset after 20 periods?" For each question $k$ and each individual $i$, we construct a measure of exponential-growth misperception that minimizes the distance between the response and the correct answer informed by equation 6 from Section 2, similarly to Goda et al. (2019). Our measure of Alpha represents the degree of exponential-growth bias, with Alpha $=1$ representing no exponential-growth bias (accurate perception) and Alpha $<1$ representing some exponential-growth bias, where the person underestimates how much assets would be worth under exponential growth. In particular, Alpha $=0$ represents the perception of growth as linear, rather than exponential. We compute the distance the response is from the correct answer and normalize it by the correct answer. Performance on these questions by OPM employees was similar to the U.S. population: between 29 and 33 percent of survey participants answered the questions within $10 \%$ of the correct value as compared to 23 to 31 percent in a representative U.S. sample (Goda et al., 2019).

\subsection{Financial literacy}

We measure basic financial literacy using the 5-item battery of financial literacy questions developed by Lusardi and Mitchell (2011) and widely used since then (Lusardi and Mitchell, 2014). These questions measure understanding of inflation, diversification, compound interest, mortgage

\footnotetext{
${ }^{9}$ The authors find a correlation between the staircase measures and incentivized experimental measures of 0.524 . This correlation is close to the test-retest correlation of 0.664 for the incentivized experiment.

${ }^{10}$ We cannot identify the indifference point for those who select the upper bound of the time staircase. In this case, we use the upper bound value plus the difference between that value and the second-to-last value to determine the indifference point. We include a dummy variable for those with these imputed values in the analysis.
} 
payments, and bond prices using multiple choice questions. OPM employees performed well on

these questions relative to the U.S. population; percent correct on each of the 5 questions ranged between 39 and 95 percent for OPM employees, while 21 to 70 percent for a representative sample of the U.S. population (Lusardi and Mitchell, 2011). Similarly, the share of employees who answered all five questions correctly was 30 percent, relative to 10 percent for the U.S. population, suggesting that OPM employees are more financially literate than average. In our subsequent analysis, we use a $z$-score of financial literacy standardized within the sample.

\subsection{Covariates by Default Regime}

Table 2 presents summary statistics of our measures of Alpha, Beta, Delta, the $z$-score for financial literacy, and our controls that are included in all subsequent analyses. The average value of Alpha for the Opt-In sample is 0.52 and for the Auto-Enrollment sample is 0.48, which implies that on average, participants in our sample exhibit exponential-growth bias. The average Beta of approximately 1 implies that, on average, the sample is time consistent. However, individuals with Beta $<1$ display present bias and those with Beta $>1$ are future biased, meaning that they over-value the future relative to today in a time inconsistent way. The mean of our sample for Alpha and Beta appear similar to the nationally-representative sample of Goda et al. (2019), while our mean Delta of 0.87 indicates greater patience than in the national population, which had a 0.70 mean. Financial literacy is standardized within sample, with a mean of approximately zero in both regimes.

From HR records, we also have data on pay, basic demographics (gender, birth year, race/ethnicity), human capital (highest education, tenure), position (non-supervisor, team leader, manager or supervisor) and work location (DC, MD, PA, VA, other) to serve as controls.

In terms of differences by default regime, the behavioral measures (Alpha, Beta, Delta and financial literacy), gender, ethnic background, and work location are all nearly identical. However, the cohorts differ substantially in tenure and associated ways. This is expected given that the change in default is tied to hire date and we are analyzing a single cross-section. The cohort hired before auto-enrollment is older, is more likely to be eligible for catch-up contributions, is paid more, is more educated, is more likely to be in a supervisory position, and has slightly less trust in the federal government. 
Table 2: Summary Statistics - Survey Measures and Controls

\begin{tabular}{|c|c|c|c|c|c|c|}
\hline & Opt-In Regime & & & & Difference & \\
\hline & mean & sd & mean & sd & $\mathrm{b}$ & $\mathrm{p}$ \\
\hline Alpha & 0.52 & 0.85 & 0.48 & 0.75 & 0.05 & $(0.28)$ \\
\hline Beta & 1.01 & 0.09 & 1.00 & 0.09 & 0.00 & $(0.50)$ \\
\hline Delta & 0.87 & 0.09 & 0.87 & 0.09 & 0.01 & $(0.19)$ \\
\hline Fin Lit (z-score) & -0.07 & 1.04 & -0.00 & 0.95 & -0.07 & $(0.16)$ \\
\hline Total Pay (\$/year) & 98456.47 & 26404.52 & 73073.82 & 32918.61 & $25382.65^{* * *}$ & $(0.00)$ \\
\hline Age & 50.87 & 9.82 & 43.37 & 10.52 & $7.51^{* * *}$ & $(0.00)$ \\
\hline Tenure in Years & 14.01 & 7.41 & 2.94 & 2.22 & $11.08^{* * *}$ & $(0.00)$ \\
\hline Trust in Fed. Gov. as Employer & 3.19 & 1.06 & 3.31 & 1.01 & $-0.12^{*}$ & $(0.03)$ \\
\hline Eligible for Catch-Up Contributions & 0.61 & 0.49 & 0.29 & 0.46 & $0.31^{* * *}$ & $(0.00)$ \\
\hline Extreme Patience & 0.16 & 0.37 & 0.16 & 0.37 & -0.00 & $(0.88)$ \\
\hline Extreme Impatience & 0.21 & 0.41 & 0.20 & 0.40 & 0.01 & $(0.57)$ \\
\hline \multicolumn{7}{|l|}{ Highest Education } \\
\hline High School & 0.18 & 0.38 & 0.15 & 0.36 & 0.02 & $(0.25)$ \\
\hline Some College or Associate & 0.19 & 0.39 & 0.14 & 0.34 & $0.05^{*}$ & $(0.01)$ \\
\hline Bachelor & 0.44 & 0.50 & 0.35 & 0.48 & $0.09^{* * *}$ & $(0.00)$ \\
\hline Post Bachelor & 0.20 & 0.40 & 0.36 & 0.48 & $-0.16^{* * *}$ & $(0.00)$ \\
\hline \multicolumn{7}{|l|}{ Race/Ethnicity: } \\
\hline White & 0.71 & 0.45 & 0.72 & 0.45 & -0.01 & $(0.69)$ \\
\hline Hispanic & 0.04 & 0.20 & 0.05 & 0.21 & -0.00 & $(0.76)$ \\
\hline Black & 0.20 & 0.40 & 0.19 & 0.39 & 0.01 & $(0.66)$ \\
\hline Other Race & 0.05 & 0.21 & 0.04 & 0.20 & 0.00 & $(0.74)$ \\
\hline \multicolumn{7}{|l|}{ Work Location: } \\
\hline DC & 0.26 & 0.44 & 0.26 & 0.44 & -0.01 & $(0.70)$ \\
\hline MD & 0.10 & 0.30 & 0.08 & 0.28 & 0.02 & $(0.26)$ \\
\hline $\mathrm{PA}$ & 0.28 & 0.45 & 0.31 & 0.46 & -0.03 & $(0.27)$ \\
\hline VA & 0.04 & 0.20 & 0.05 & 0.22 & -0.01 & $(0.42)$ \\
\hline Other Location & 0.32 & 0.47 & 0.30 & 0.46 & 0.03 & $(0.27)$ \\
\hline \multicolumn{7}{|l|}{ Job Position: } \\
\hline Non-Supervisory & 0.81 & 0.39 & 0.93 & 0.25 & $-0.12^{* * *}$ & $(0.00)$ \\
\hline Team Leader & 0.04 & 0.21 & 0.02 & 0.13 & $0.03^{* *}$ & $(0.00)$ \\
\hline Supervisor or Manager & 0.14 & 0.35 & 0.05 & 0.21 & $0.10^{* * *}$ & $(0.00)$ \\
\hline \multicolumn{7}{|l|}{ Gender: } \\
\hline Female & 0.57 & 0.50 & 0.53 & 0.50 & 0.05 & $(0.08)$ \\
\hline Male & 0.43 & 0.50 & 0.47 & 0.50 & -0.05 & $(0.08)$ \\
\hline Observations & 735 & & 661 & & 1396 & \\
\hline
\end{tabular}




\section{Results}

\subsection{Main Results}

We analyze the relationship between survey-based measures of long-run discount rates (Delta), present bias (Beta), exponential-growth bias (Alpha) and financial literacy and contribution choices separately by enrollment regime. We test whether the measured parameters have different effects on savings outcomes based on whether employees had to opt-in or would have been auto-enrolled at the time of hire.

The first set of outcomes in Table 3 considers our measures in the likelihood of contributing at the default rate. For employees hired in the opt-in regime, this variable represents whether the employee is still at a zero percent contribution rate. For those hired in the auto-enrollment regime, it represents whether the employee is at a 3 percent contribution rate and includes both those who were passively defaulted into the 3 percent contribution rate and those who actively selected it. We test whether the role of long-run discount rates, present bias, exponential-growth bias and financial literacy differs across enrollment regime and include $p$-values reporting the results from a test of equality across enrollment regimes at the bottom of the table.

The results show no evidence that Beta is a predictor of remaining at the default when the default contribution rate is zero in Column (1), but strong evidence that lower levels of Beta (i.e., more present biased and more tendency to procrastinate) are associated with a higher likelihood of remaining at the default when the default contribution rate is 3 percent in Column (2). The coefficient on Beta of -0.496 in Column (2) of Table 3 implies that a one standard deviation (0.09) decrease in Beta is associated with a 4.5 percentage point (30 percent) higher probability of being at the default. This coefficient is statistically distinguishable from the coefficient on Beta in Column (1) $(p=0.007)$ indicating that present bias has a significantly larger effect in the auto-enrollment regime than the opt-in regime.

The outcome in Column (3) of Table 3 represents whether employees were passively enrolled into the TSP. Because this outcome variable is only available for those hired in the auto-enrollment regime, we restrict just to this subsample, as indicated in a row below the regression results. Failing to make an active choice is strongly correlated with Beta, but we find no evidence that it is correlated with Alpha, Delta, or financial literacy. The coefficient of -0.366 on Beta implies 
that a one standard deviation decrease in Beta, corresponding to more present bias, is associated with a 3.3 percentage point higher probability of passive behavior. The magnitude is economically significant, representing a 28 percent change relative to the mean. Unsurprisingly, the results are similar to those reported in Column (2), given that the majority of employees who contribute at the default rate are there passively.

In Columns (4) and (5) we examine the probability of being at $0 \%$ contributions under the two regimes. ${ }^{11}$ The unconditional probability of being at $0 \%$ under opt-in $(d=0 \%)(0.088)$ is larger than the probability under auto-enrollment $(d=3 \%)(0.048)$ with $p<0.01$. For financial literacy, among those hired during opt-in, the coefficient is statistically significant (Column (4)). The coefficient of -0.030 represents a 28 percent decrease in the probability of being at the default from a one standard deviation (0.82) increase of financial literacy. By contrast, the coefficient on financial literacy is not statistically significant among those hired under auto-enrollment (Column (5)), and is statistically different from the coefficient in Column (4) $(p=0.019)$. Therefore, our results suggest that higher financial literacy reduces non-participation more in the opt-in regime relative to the auto-enrollment regime. Finally, in Columns (6) and (7), we examine whether our measures predict which employees maximize the employer match by contributing at least 5 percent of salary. Unexpectedly, we find that Beta is negatively associated with maximizing the match under the opt-in regime, but this coefficient is only statistically significant at marginal levels $(p<0.10)$. Neither Alpha, Delta, nor financial literacy predict maximizing the match in either enrollment regime.

\footnotetext{
${ }^{11}$ Note Column (4) is a replica of Column (1) because the default equals $0 \%$ before auto-enrollment.
} 
Table 3: Relationship between Alpha, Beta, Delta, Fin Lit and TSP Outcomes (Default, Passive, 0\%, Max Match)

\begin{tabular}{|c|c|c|c|c|c|c|c|}
\hline & $\begin{array}{c}(1) \\
\text { At Default } \\
\end{array}$ & $\begin{array}{c}(2) \\
\text { At Default }\end{array}$ & $\begin{array}{c}(3) \\
\text { Passive } \\
\end{array}$ & $\begin{array}{c}(4) \\
\text { At } 0 \% \\
\end{array}$ & $\begin{array}{c}(5) \\
\text { At } 0 \% \\
\end{array}$ & $\begin{array}{l}(6) \\
\text { At/Above Max. Match }\end{array}$ & $\begin{array}{c}(7) \\
\text { At/Above Max. Match }\end{array}$ \\
\hline Alpha & $\begin{array}{l}-0.015 \\
(0.012)\end{array}$ & $\begin{array}{l}-0.020 \\
(0.018)\end{array}$ & $\begin{array}{l}-0.002 \\
(0.016)\end{array}$ & $\begin{array}{l}-0.015 \\
(0.012)\end{array}$ & $\begin{array}{l}0.015 \\
(0.015)\end{array}$ & $\begin{array}{c}0.003 \\
(0.021)\end{array}$ & $\begin{array}{l}-0.003 \\
(0.027)\end{array}$ \\
\hline Beta & $\begin{array}{c}0.182 \\
(0.156)\end{array}$ & $\begin{array}{c}-0.496^{* *} \\
(0.199)\end{array}$ & $\begin{array}{c}-0.366^{* *} \\
(0.183)\end{array}$ & $\begin{array}{c}0.182 \\
(0.156)\end{array}$ & $\begin{array}{l}-0.140 \\
(0.128)\end{array}$ & $\begin{array}{c}-0.477^{*} \\
(0.245)\end{array}$ & $\begin{array}{l}-0.011 \\
(0.261)\end{array}$ \\
\hline Delta & $\begin{array}{l}-0.023 \\
(0.137)\end{array}$ & $\begin{array}{l}-0.061 \\
(0.206)\end{array}$ & $\begin{array}{c}0.032 \\
(0.193)\end{array}$ & $\begin{array}{l}-0.023 \\
(0.137)\end{array}$ & $\begin{array}{l}-0.021 \\
(0.125)\end{array}$ & $\begin{array}{c}0.031 \\
(0.255)\end{array}$ & $\begin{array}{l}-0.355 \\
(0.268)\end{array}$ \\
\hline Fin Lit (z-score) & $\begin{array}{c}-0.030^{* *} \\
(0.013)\end{array}$ & $\begin{array}{l}-0.008 \\
(0.016)\end{array}$ & $\begin{array}{l}-0.008 \\
(0.014)\end{array}$ & $\begin{array}{c}-0.030^{* *} \\
(0.013)\end{array}$ & $\begin{array}{c}0.009 \\
(0.010)\end{array}$ & $\begin{array}{c}0.005 \\
(0.019)\end{array}$ & $\begin{array}{l}-0.023 \\
(0.022)\end{array}$ \\
\hline Some College or Associate & $\begin{array}{c}0.018 \\
(0.047)\end{array}$ & $\begin{array}{l}-0.033 \\
(0.056)\end{array}$ & $\begin{array}{c}-0.110^{* *} \\
(0.052)\end{array}$ & $\begin{array}{c}0.018 \\
(0.047)\end{array}$ & $\begin{array}{l}0.010 \\
(0.042)\end{array}$ & $\begin{array}{c}0.007 \\
(0.062)\end{array}$ & $\begin{array}{l}-0.038 \\
(0.074)\end{array}$ \\
\hline Bachelor & $\begin{array}{c}-0.083^{* *} \\
(0.040)\end{array}$ & $\begin{array}{l}0.010 \\
(0.050)\end{array}$ & $\begin{array}{l}-0.043 \\
(0.048)\end{array}$ & $\begin{array}{c}-0.083^{* *} \\
(0.040)\end{array}$ & $\begin{array}{l}-0.044 \\
(0.032)\end{array}$ & $\begin{array}{c}0.092 \\
(0.056)\end{array}$ & $\begin{array}{c}0.031 \\
(0.062)\end{array}$ \\
\hline Post-Bachelor & $\begin{array}{c}-0.105^{* *} \\
(0.043)\end{array}$ & $\begin{array}{l}-0.011 \\
(0.051)\end{array}$ & $\begin{array}{l}-0.055 \\
(0.048)\end{array}$ & $\begin{array}{c}-0.105^{* *} \\
(0.043)\end{array}$ & $\begin{array}{l}-0.038 \\
(0.036)\end{array}$ & $\begin{array}{c}0.099 \\
(0.068)\end{array}$ & $\begin{array}{c}0.003 \\
(0.066)\end{array}$ \\
\hline White & $\begin{array}{l}0.035 \\
(0.035)\end{array}$ & $\begin{array}{l}-0.026 \\
(0.062)\end{array}$ & $\begin{array}{l}0.060^{* *} \\
(0.026)\end{array}$ & $\begin{array}{l}0.035 \\
(0.035)\end{array}$ & $\begin{array}{l}-0.001 \\
(0.035)\end{array}$ & $\begin{array}{l}0.093 \\
(0.086)\end{array}$ & $\begin{array}{l}0.023 \\
(0.098)\end{array}$ \\
\hline Hispanic & $\begin{array}{l}0.044 \\
(0.054)\end{array}$ & $\begin{array}{l}-0.008 \\
(0.082)\end{array}$ & $\begin{array}{l}0.117^{*} \\
(0.061)\end{array}$ & $\begin{array}{l}0.044 \\
(0.054)\end{array}$ & $\begin{array}{l}-0.002 \\
(0.049)\end{array}$ & $\begin{array}{l}0.084 \\
(0.124)\end{array}$ & $\begin{array}{l}-0.154 \\
(0.131)\end{array}$ \\
\hline Black & $\begin{array}{l}0.100^{* *} \\
(0.041)\end{array}$ & $\begin{array}{c}0.012 \\
(0.069)\end{array}$ & $\begin{array}{c}0.125^{* * *} \\
(0.037)\end{array}$ & $\begin{array}{l}0.100^{* *} \\
(0.041)\end{array}$ & $\begin{array}{l}0.067 \\
(0.046)\end{array}$ & $\begin{array}{l}0.005 \\
(0.094)\end{array}$ & $\begin{array}{l}-0.147 \\
(0.105)\end{array}$ \\
\hline Male & $\begin{array}{c}0.062^{* * *} \\
(0.023)\end{array}$ & $\begin{array}{c}0.003 \\
(0.028)\end{array}$ & $\begin{array}{l}-0.011 \\
(0.026)\end{array}$ & $\begin{array}{c}0.062^{* * * *} \\
(0.023)\end{array}$ & $\begin{array}{c}-0.043^{* *} \\
(0.017)\end{array}$ & $\begin{array}{l}-0.013 \\
(0.039)\end{array}$ & $\begin{array}{l}0.004 \\
(0.040)\end{array}$ \\
\hline Eligible for Catch-Up Contributions & $\begin{array}{l}-0.040 \\
(0.039)\end{array}$ & $\begin{array}{l}-0.024 \\
(0.052)\end{array}$ & $\begin{array}{l}-0.028 \\
(0.050)\end{array}$ & $\begin{array}{l}-0.040 \\
(0.039)\end{array}$ & $\begin{array}{l}-0.032 \\
(0.040)\end{array}$ & $\begin{array}{c}0.018 \\
(0.067)\end{array}$ & $\begin{array}{l}0.050 \\
(0.080)\end{array}$ \\
\hline Constant & $\begin{array}{c}0.018 \\
(0.316) \\
\end{array}$ & $\begin{array}{c}1.377^{* * *} \\
(0.420) \\
\end{array}$ & $\begin{array}{l}0.965^{* *} \\
(0.398) \\
\end{array}$ & $\begin{array}{c}0.018 \\
(0.316) \\
\end{array}$ & $\begin{array}{l}0.482^{*} \\
(0.289) \\
\end{array}$ & $\begin{array}{c}1.595^{* * *} \\
(0.610) \\
\end{array}$ & $\begin{array}{l}-0.211 \\
(0.535) \\
\end{array}$ \\
\hline Sample & Opt-In Regime & Auto-Enroll Regime & Auto-Enroll Regime & Opt-In Regime & Auto-Enroll Regime & Opt-In Regime & Auto-Enroll Regime \\
\hline $\begin{array}{l}\text { p-value for } \\
\text { Equality Across Groups } \\
\text { Alpha } \\
\text { Beta } \\
\text { Delta } \\
\text { Fin Lit } \\
\text { All Four }\end{array}$ & & $\begin{array}{l}0.817 \\
0.007 \\
0.878 \\
0.286 \\
0.054\end{array}$ & & & $\begin{array}{l}0.115 \\
0.112 \\
0.992 \\
0.019 \\
0.013\end{array}$ & & $\begin{array}{l}0.845 \\
0.193 \\
0.298 \\
0.319 \\
0.184\end{array}$ \\
\hline $\begin{array}{l}\text { Mean DV } \\
\text { R-squared } \\
\text { Observations }\end{array}$ & $\begin{array}{l}0.088 \\
0.091 \\
735\end{array}$ & $\begin{array}{c}0.147 \\
0.099 \\
661\end{array}$ & $\begin{array}{l}0.118 \\
0.116 \\
651\end{array}$ & $\begin{array}{l}0.088 \\
0.091 \\
735\end{array}$ & $\begin{array}{c}0.048 \\
0.053 \\
661\end{array}$ & $\begin{array}{l}0.614 \\
0.087 \\
735\end{array}$ & $\begin{array}{c}0.576 \\
0.075 \\
661\end{array}$ \\
\hline
\end{tabular}

Robust standard errors reported. Dependent variable in column heading. All specifications also include controls for Salary, Salary Squared, Age, Age Squared, Years of Tenure, Years of Tenure Squared, binary variables for Extreme Patience and Extreme Impatience, Work Location, Job Position, and Trust in Fed. Gov. as Employer. ${ }^{*} \mathrm{p}$ $<0.10,{ }^{* *} \mathrm{p}<0.05, * * * \mathrm{p}<0.01$. 
In Table 4 we report results similar to Table 3 but for annual TSP contributions, TSP rate as a percent of salary, and an indicator for being at the annual maximum. Column (1) shows that there is no statistically significant effect of Alpha or Beta in the opt-in regime, but the coefficient on financial literacy is statistically significant. A standard deviation increase in financial literacy is associated with a $\$ 698$ or 8 percent increase in annual contributions under the opt-in regime. In the auto-enrollment regime, Column (2), higher Beta (less present bias) is associated with higher contributions. A one standard deviation decrease in Beta is associated with $\$ 369$ or a 7 percent decrease in annual contributions. As we saw in TSP participation in Table 3, the coefficients on financial literacy are statistically different from one another across enrollment regime $(p=0.019)$, indicating that financial literacy has a stronger effect on contributions in the opt-in regime. Consistent with theory, the long run discount factor Delta is associated with higher annual contributions in both regimes.

Columns (3) and (4) in Table 4 repeat the analysis in Columns (1) and (2) but for TSP contributions as a percent of salary rather than annual amount. The results are qualitatively similar to those in Columns (1) and (2): the coefficient on Beta is higher in the auto-enrollment regime, but not statistically distinguishable from the coefficient on Beta in the opt-in regime, and the coefficient on financial literacy is higher in the opt-in regime relative to the auto-enrollment regime $(p=0.052)$. These results indicate that the results in Column (1) and (2) still hold after adjusting for the fact that annual contributions for employees hired in the opt-in regime may have higher contributions simply because they contribute a certain share of their salary and their salaries are higher.

Finally, we examine the relationship between our measures and contributing the $\$ 18,000$ per year maximum annual contribution. Column (5) shows that in the opt-in regime, one standard deviation higher financial literacy increases the probability of capping out total contributions by 2.5 percentage points or 20 percent; however, this coefficient is not statistically different across enrollment regime at conventional levels. Alpha and Beta are not significant predictors in either regime. 
Table 4: Relationship between Alpha, Beta, Delta, Fin Lit and TSP Outcomes (Amount, Rate, Cap)

\begin{tabular}{|c|c|c|c|c|c|c|}
\hline & $\begin{array}{c}(1) \\
\text { TSP Amt. }\end{array}$ & $\begin{array}{l}(2) \\
\text { TSP Amt. }\end{array}$ & $\begin{array}{c}(3) \\
\text { TSP Rate }\end{array}$ & $\begin{array}{c}(4) \\
\text { TSP Rate }\end{array}$ & $\begin{array}{c}(5) \\
\text { At Cap }\end{array}$ & At Cap \\
\hline Alpha & $\begin{array}{l}281.624 \\
(245.088)\end{array}$ & $\begin{array}{l}140.051 \\
(196.593)\end{array}$ & $\begin{array}{c}0.172 \\
(0.252)\end{array}$ & $\begin{array}{c}0.033 \\
(0.247)\end{array}$ & $\begin{array}{l}0.000 \\
(0.013)\end{array}$ & $\begin{array}{l}0.004 \\
(0.008)\end{array}$ \\
\hline Beta & $\begin{array}{c}2749.562 \\
(2951.529)\end{array}$ & $\begin{array}{l}4096.443^{* *} \\
(1701.863)\end{array}$ & $\begin{array}{l}1.242 \\
(3.010)\end{array}$ & $\begin{array}{l}3.728^{*} \\
(2.028)\end{array}$ & $\begin{array}{l}0.168 \\
(0.148)\end{array}$ & $\begin{array}{l}0.090 \\
(0.074)\end{array}$ \\
\hline Delta & $\begin{array}{l}5561.091^{*} \\
(2854.447)\end{array}$ & $\begin{array}{c}5180.661^{* * *} \\
(1956.209)\end{array}$ & $\begin{array}{l}5.392^{*} \\
(2.834)\end{array}$ & $\begin{array}{l}4.974^{* *} \\
(2.453)\end{array}$ & $\begin{array}{l}0.295^{*} \\
(0.166)\end{array}$ & $\begin{array}{c}0.253^{* * *} \\
(0.091)\end{array}$ \\
\hline Fin Lit (z-score) & $\begin{array}{c}697.529^{* * *} \\
(237.200)\end{array}$ & $\begin{array}{c}39.942 \\
(147.704)\end{array}$ & $\begin{array}{c}0.710^{* * *} \\
(0.227)\end{array}$ & $\begin{array}{c}0.111 \\
(0.208)\end{array}$ & $\begin{array}{c}0.025^{* *} \\
(0.011)\end{array}$ & $\begin{array}{l}-0.000 \\
(0.008)\end{array}$ \\
\hline Some College or Associate & $\begin{array}{l}-336.674 \\
(692.206)\end{array}$ & $\begin{array}{c}364.230 \\
(484.416)\end{array}$ & $\begin{array}{l}-0.139 \\
(0.744)\end{array}$ & $\begin{array}{l}1.087 \\
(0.835)\end{array}$ & $\begin{array}{l}-0.042 \\
(0.033)\end{array}$ & $\begin{array}{c}0.009 \\
(0.021)\end{array}$ \\
\hline Bachelor & $\begin{array}{c}1925.845^{* * *} \\
(663.274)\end{array}$ & $\begin{array}{c}545.512 \\
(359.457)\end{array}$ & $\begin{array}{c}2.184^{* * * *} \\
(0.709)\end{array}$ & $\begin{array}{c}0.772 \\
(0.496)\end{array}$ & $\begin{array}{c}0.029 \\
(0.034)\end{array}$ & $\begin{array}{l}-0.010 \\
(0.012)\end{array}$ \\
\hline Post-Bachelor & $\begin{array}{c}2940.117^{* * *} \\
(826.557)\end{array}$ & $\begin{array}{c}633.866 \\
(435.926)\end{array}$ & $\begin{array}{c}3.127^{* * *} \\
(0.838)\end{array}$ & $\begin{array}{c}0.793 \\
(0.613)\end{array}$ & $\begin{array}{l}0.030 \\
(0.044)\end{array}$ & $\begin{array}{l}0.018 \\
(0.014)\end{array}$ \\
\hline White & $\begin{array}{c}-367.927 \\
(1117.444)\end{array}$ & $\begin{array}{c}-1653.945^{*} \\
(964.865)\end{array}$ & $\begin{array}{l}-0.547 \\
(1.083)\end{array}$ & $\begin{array}{l}-1.663 \\
(1.030)\end{array}$ & $\begin{array}{l}-0.091 \\
(0.073)\end{array}$ & $\begin{array}{l}0.025 \\
(0.046)\end{array}$ \\
\hline Hispanic & $\begin{array}{l}-1588.220 \\
(1388.516)\end{array}$ & $\begin{array}{l}-1084.639 \\
(1248.907)\end{array}$ & $\begin{array}{l}-1.895 \\
(1.361)\end{array}$ & $\begin{array}{l}-0.626 \\
(1.534)\end{array}$ & $\begin{array}{c}-0.232^{* * *} \\
(0.078)\end{array}$ & $\begin{array}{c}0.019 \\
(0.064)\end{array}$ \\
\hline Black & $\begin{array}{c}-2781.359^{* *} \\
(1205.207)\end{array}$ & $\begin{array}{c}-2885.254^{* * * *} \\
(1039.709)\end{array}$ & $\begin{array}{c}-2.884^{* *} \\
(1.166)\end{array}$ & $\begin{array}{c}-3.050^{* * * *} \\
(1.136)\end{array}$ & $\begin{array}{c}-0.177^{* *} \\
(0.078)\end{array}$ & $\begin{array}{l}0.023 \\
(0.045)\end{array}$ \\
\hline Male & $\begin{array}{l}-386.386 \\
(472.595)\end{array}$ & $\begin{array}{l}-200.483 \\
(321.459)\end{array}$ & $\begin{array}{l}-0.326 \\
(0.477)\end{array}$ & $\begin{array}{l}-0.166 \\
(0.429)\end{array}$ & $\begin{array}{r}-0.047^{*} \\
(0.027)\end{array}$ & $\begin{array}{c}0.007 \\
(0.016)\end{array}$ \\
\hline Eligible for Catch-Up Contributions & $\begin{array}{c}2579.677^{* * * *} \\
(768.946)\end{array}$ & $\begin{array}{l}-298.523 \\
(623.772)\end{array}$ & $\begin{array}{c}2.263^{* * * *} \\
(0.759)\end{array}$ & $\begin{array}{l}0.586 \\
(0.813)\end{array}$ & $\begin{array}{c}0.069 \\
(0.046)\end{array}$ & $\begin{array}{l}0.015 \\
(0.032)\end{array}$ \\
\hline Constant & $\begin{array}{c}-14747.638^{* *} \\
(6737.595) \\
\end{array}$ & $\begin{array}{c}-6581.929^{*} \\
(3686.124) \\
\end{array}$ & $\begin{array}{l}-6.284 \\
(6.810)\end{array}$ & $\begin{array}{l}-4.396 \\
(4.405)\end{array}$ & $\begin{array}{c}-1.016^{* * * *} \\
(0.381)\end{array}$ & $\begin{array}{c}-0.487^{* * *} \\
(0.179)\end{array}$ \\
\hline Sample & Opt-In Regime & Auto-Enroll Regime & Opt-In Regime & Auto-Enroll Regime & Opt-In Regime & Auto-Enroll Regime \\
\hline $\begin{array}{l}p \text {-value for } \\
\text { Equality Across Groups } \\
\text { Alpha } \\
\text { Beta } \\
\text { Delta } \\
\text { Fin Lit } \\
\text { All Four }\end{array}$ & & $\begin{array}{l}0.652 \\
0.693 \\
0.913 \\
0.019 \\
0.183\end{array}$ & & $\begin{array}{l}0.694 \\
0.494 \\
0.911 \\
0.052 \\
0.345\end{array}$ & & $\begin{array}{l}0.796 \\
0.641 \\
0.826 \\
0.070 \\
0.457\end{array}$ \\
\hline $\begin{array}{l}\text { Mean DV } \\
\text { R-squared } \\
\text { Observations }\end{array}$ & $\begin{array}{c}8699.480 \\
0.283 \\
735\end{array}$ & $\begin{array}{c}5160.133 \\
0.456 \\
661\end{array}$ & $\begin{array}{c}8.692 \\
0.150 \\
735\end{array}$ & $\begin{array}{c}6.600 \\
0.123 \\
661 \\
\end{array}$ & $\begin{array}{c}0.131 \\
0.144 \\
735\end{array}$ & $\begin{array}{c}0.042 \\
0.140 \\
661\end{array}$ \\
\hline
\end{tabular}

Robust standard errors reported. Dependent variable in column heading. All specifications also include controls for Salary, Salary Squared, Age, Age Squared, Years of Tenure, Years of Tenure Squared, binary variables for Extreme Patience and Extreme Impatience, Work Location, Job Position, and Trust in Fed. Gov. as Employer. ${ }^{*} \mathrm{p}<0.10,{ }^{* *} \mathrm{p}<0.05,{ }^{* * *} \mathrm{p}<0.01$. 


\subsection{Robustness}

The paper's basic exercise is to study if and how relationships between stable, individual-level characteristics (exponential-growth bias, long-run discount factor, present bias, and financial literacy) and retirement contribution outcomes differ for those hired under different default regimes. Ideally, we would observe contribution outcomes from the time of hire for the full sample. In fact, we observe contribution decisions as of April 2017, which for some is many years after the time of hire. Those hired before the change will mechanically have longer tenure and tend to be older and have higher pay. We can observe and control for these time-varying determinants of contribution decisions that are correlated with default regime at hire. Imbalances in them are expected and relatively easy to manage.

A deeper concern is that individuals select in or select out of the sample differently across the two regimes. This could happen due to both observable and unobservable characteristics. Studies with a random-assignment or regression-discontinuity design commonly consider evidence of balance on time-invariant observables as informative about the credibility of their identifying assumption of balance on unobservables. We offer evidence in the same spirit.

If the regime-change date was not coincident with any change in the hiring process, we would expect the group of people hired in a narrow bandwidth of time before the regime-change to be quite similar to those hired within a narrow bandwidth of time after the regime change. ${ }^{12}$ With a narrower bandwidth, the groups are likely to be more similar, but smaller in number. As the bandwidth widens, the groups grow in size but they may become less similar due to secular changes in the population or organization. This is similar to a bias-variance trade-off familiar in regressiondiscontinuity designs. Our main analysis uses the entire sample of workers observed in April 2017. At the extremes, this includes someone hired 35 years before the regime-change date and 7 years after it.

To address these concerns about selection, we offer two kinds of evidence. First, we show that our key independent variables are balanced as the bandwidth expands. Second, we show that the primary regression results are stable when we exclude individuals hired further from the regimechange date. Table 5 presents the test of balance for our main predictors. The sample includes

\footnotetext{
${ }^{12}$ In speaking with OPM staff, our understanding is that there were no changes in the hiring process coincident with the change in enrollment regime.
} 
employees hired within $b$ years of August 2010, the date of the enrollment-regime change, and where $b$ varies between 1 and $15+$ years. Within this sample, we compute means for the subsamples hired on either side of the regime-change threshold. Each cell reports the difference in the average of the row-variable among those hired before and those hired after the default change along with a standard error. There are no significant differences in mean exponential-growth bias or present bias in the two different regimes. For each variable, the differences between the groups are small and never significant even at $10 \% .{ }^{13}$ This mitigates concern that our findings are driven by differential selection into default regime based on our behavioral measures.

${ }^{13}$ Appendix Table A.3 presents analogous results for all control variables. 
Table 5: Differences in Alpha, Beta, Delta, Fin Lit across Enrollment Regime by Bandwidth

\begin{tabular}{|c|c|c|c|c|c|c|c|c|c|c|c|c|c|c|c|c|}
\hline Alpha & $\begin{array}{l}\frac{(1)}{0.043} \\
(0.105)\end{array}$ & $\begin{array}{l}.21 \\
(0.0655) \\
(0.085)\end{array}$ & $\begin{array}{l}\frac{(3)}{-0.002} \\
(0.074)\end{array}$ & $\begin{array}{l}\frac{(4)}{(0.099} \\
0.066)\end{array}$ & $\begin{array}{l}\frac{(5)}{0.019} \\
(0.060)\end{array}$ & $\begin{array}{l}\frac{610}{0.030)} \\
(0.050)\end{array}$ & $\begin{array}{l}\frac{(7)}{0.019} \\
(0.046)\end{array}$ & $\begin{array}{l}\frac{(8)}{0.024} \\
(0.046)\end{array}$ & $\begin{array}{l}\frac{(9)}{0.014} \\
(0.046)\end{array}$ & $\begin{array}{l}\frac{(10)}{0.013} \\
(0.045)\end{array}$ & $\begin{array}{l}\frac{(11)}{0.014} \\
(0.045)\end{array}$ & $\begin{array}{l}\frac{(12)}{0.019} \\
(0.045)\end{array}$ & $\frac{(13)}{(0.022)}$ & $\begin{array}{l}\frac{(14)}{0.027} \\
(0.045)\end{array}$ & $\begin{array}{l}\frac{(15)}{(0.032)} \\
(0.045)\end{array}$ & $\begin{array}{l}\frac{(16)}{0.047} \\
(0.043)\end{array}$ \\
\hline Beta & $\begin{array}{c}-0.010) \\
(0.011)\end{array}$ & $\begin{array}{c}-0.006) \\
(0.0099)\end{array}$ & $\begin{array}{l}0.003 \\
(0.008)\end{array}$ & $\begin{array}{l}0.002 \\
(0.007)\end{array}$ & $\begin{array}{l}0.001 \\
(0.006)\end{array}$ & $\begin{array}{c}-0.002) \\
(0.005)\end{array}$ & $\begin{array}{l}0.001) \\
(0.005)\end{array}$ & $\begin{array}{l}0.002 \\
(0.005)\end{array}$ & $\begin{array}{l}0.002 \\
(0.005)\end{array}$ & $\begin{array}{l}0.001) \\
(0.005)\end{array}$ & $\begin{array}{l}0.001) \\
(0.005)\end{array}$ & $\begin{array}{l}0.001 \\
(0.005)\end{array}$ & $\left.\begin{array}{l}0.000 \\
(0.005)\end{array}\right)$ & $\begin{array}{l}0.001 \\
(0.005)\end{array}$ & $\begin{array}{l}0.001 \\
(0.005)\end{array}$ & $\begin{array}{c}0.003 \\
(0.005)\end{array}$ \\
\hline Delta & $\begin{array}{l}0.008 \\
(0.013)\end{array}$ & $\left.\begin{array}{c}0.001) \\
(0.010)\end{array}\right)$ & $\begin{array}{l}0.003 \\
(0.009)\end{array}$ & $\begin{array}{l}0.004 \\
(0.008)\end{array}$ & $\left.\begin{array}{l}0.007 \\
(0.007)\end{array}\right)$ & $\begin{array}{l}0.007 \\
(0.006)\end{array}$ & $\begin{array}{l}0.006) \\
(0.005)\end{array}$ & $\begin{array}{l}0.005 \\
(0.005)\end{array}$ & $\begin{array}{l}0.006 \\
(0.005)\end{array}$ & $\begin{array}{l}0.006) \\
(0.005)\end{array}$ & $\begin{array}{l}0.005 \\
(0.005)\end{array}$ & $\begin{array}{l}0.005) \\
(0.005)\end{array}$ & $\begin{array}{l}0.005 \\
(0.005)\end{array}$ & $\begin{array}{l}0.005 \\
(0.005)\end{array}$ & $\begin{array}{l}0.005) \\
(0.005)\end{array}$ & $\begin{array}{l}0.006 \\
(0.005)\end{array}$ \\
\hline $\begin{array}{l}\text { Fin Lit (z-score) } \\
\text { Bandwidth }\end{array}$ & $\begin{array}{l}-0.120 \\
\frac{0.138)}{(0.1 \text { Year }} \\
\langle<\text { Year }\end{array}$ & $\begin{array}{l}-0.086 \\
\frac{0.088)}{(0.108)} \\
\langle 2 \text { Year }\end{array}$ & 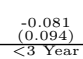 & $\begin{array}{r}-0.101 \\
-(0.082) \\
\langle<4 \text { Year }\end{array}$ & $\begin{array}{l}0.002 \\
0.0072) \\
\langle 50 \text { Year } \\
<5 \text { Year }\end{array}$ & $\begin{array}{l}\frac{-0.050}{(0.061)} \\
\frac{0.061}{<6 \text { Year }}\end{array}$ & 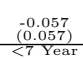 & $\begin{array}{l}-0.054 \\
\frac{-0.056)}{\langle 8.0 \text { Year }} \\
<\text { Year }\end{array}$ & 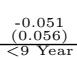 & $\begin{array}{l}\frac{-0.048}{(0.055)} \\
<10 \text { Year } \\
<10\end{array}$ & $\begin{array}{c}-0.050 \\
\frac{(0.055)}{\langle 11} \text { Year } \\
\langle 0 \text { Year }\end{array}$ & 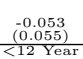 & $\begin{array}{l}\frac{-0.060}{(0.055)} \\
(13 \text { Year }\end{array}$ & $\begin{array}{l}\frac{-0.056}{(0.055)} \\
(10.05 \text { Year }\end{array}$ & $\begin{array}{c}-0.057 \\
0.055) \\
\langle 15 \text { Year } \\
15\end{array}$ & $\begin{array}{c}-0.074 \\
\frac{(0.053)}{\text { All Years }}\end{array}$ \\
\hline Observations & 206 & 341 & 439 & 559 & 727 & 1041 & 1195 & 1209 & 1231 & 1238 & 1258 & 1270 & 1276 & 1282 & 1287 & 1396 \\
\hline
\end{tabular}

Each cell presents the row-variable difference in means (SE) between those hired in the bandwidth before and after the regime change date. ${ }^{*} \mathrm{p}<0.10$, $* * \mathrm{p}<0.05, * * * \mathrm{p}<0.01$. 
Figure 1: Robustness of Relationship between Beta, Fin Lit and TSP Outcomes by Sample Bandwidth
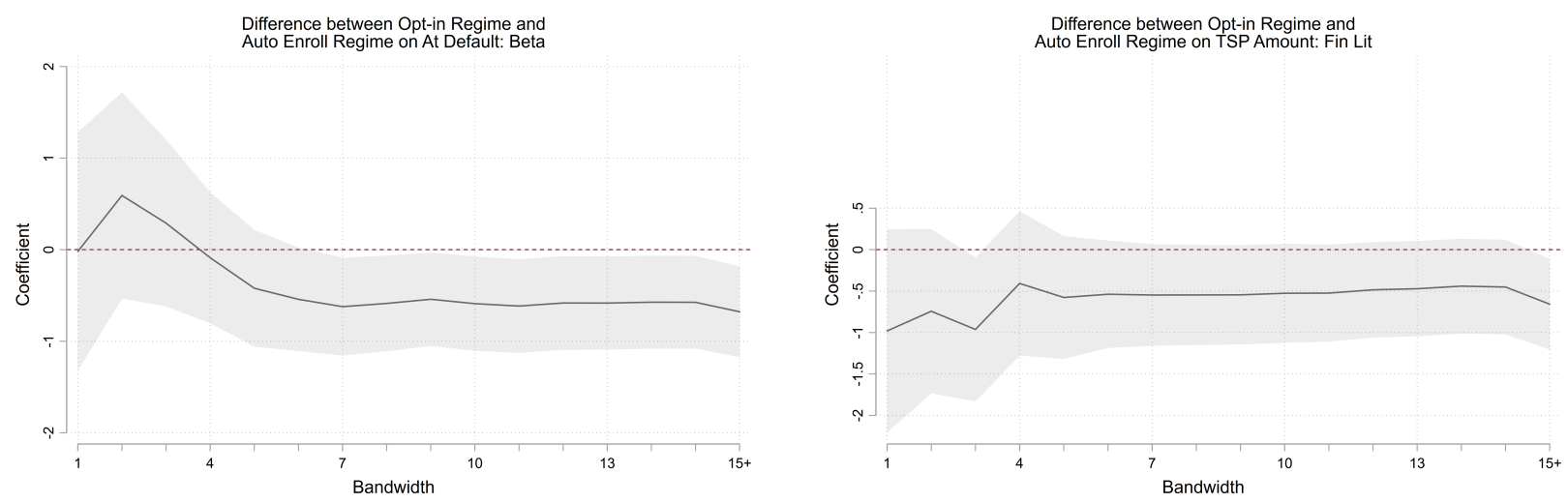

Next, we perform the analysis in Tables 3 and 4 but trim the samples to include only those hired within various $b$-bandwidths of the regime change date. We show the results for two of our main findings in Figure 1. The left panel of Figure 1 depicts the estimated difference in the coefficient on Beta and its 95 percent confidence interval for the "At Default" outcome across regimes as a function of the bandwidth $b$. The right panel of Figure 1 depicts the estimated difference in the coefficient on financial literacy and its 95 percent confidence interval for the TSP annual contribution outcome as a function of the bandwidth $b$. For financial literacy, the finding of a larger negative relationship with TSP contributions for the opt-in regime is robust to the bandwidth. For Beta, the finding of a larger negative relationship with being at the default is less stable at smaller bandwidths, yet the full sample coefficient estimate $(15+$ years $)$ is within the 95 percent confidence interval for all bandwidths except for 2 and 3 years. We focus on just these 2 coefficients because they represent our main findings. Figures depicting the stability of estimated differences in coefficient estimates across enrollment regime and their 95 percent confidence intervals by $b$ for all four of our main predictors and six outcomes are shown in Appendix Figure A.1. In general, these figures show that the estimated differences in our coefficients across regime is stable across bandwidth though confidence intervals are wider as the sample size declines.

Another possible concern regarding the interpretation of results is that the associations are generated through reverse causality. Perhaps past retirement contribution behavior affects present bias and financial literacy. If so, this would imply that under the opt-in regime, individuals who selected lower contribution amounts caused themselves to have lower financial literacy, and under 
the auto-enrollment regime, individuals who selected the default caused themselves to have more present bias. Lusardi, Michaud and Mitchell (2017) present a lifecycle-savings framework in which financial literacy is endogenous. Obtaining more financial literacy yields higher returns and this is more valuable for higher earners. Their model has a causal relationship from income to financial literacy. In our context, it could be that people under the opt-in regime who had selected lower contribution amounts would have less reason to become financially literate as they would have less retirement savings to think about. But the questions used for the financial literacy measure were quite general (inflation, diversification, compound interest, mortgage payments, and bond prices) and had nothing to do with retirement savings specifically. Such basic financial knowledge would be useful for anyone with any financial assets, which all employees in our sample have due to the agency's mandatory contribution to TSP. It is even less clear how choosing the default under auto-enrollment would cause a person to be more present biased. It is possible that those induced to a $3 \%$ contribution rate are saving more than is comfortable and this imposed illiquidity causes people to answer "money earlier or later" questions in a more impatient manner. But if this were true, then we would also find Delta to be negatively associated with being at the default, but the coefficient on Delta is not significant.

One additional concern is whether we have measurement error in the behavioral factors given they were assessed using survey-based elicitation. While we use the average of multiple measures of our parameters in the main analysis to mitigate the influence of any measurement error, a different strategy is to use an obviously-related instrumental variables (ORIV) approach (Gillen et al., 2017). ${ }^{14}$ Overall, we find that our findings are robust to using the ORIV approach (see Appendix Appendix B).

\section{Discussion}

The conceptual framework in Section 2 built on several strands of literature regarding the nature of default effects. We now briefly return to these in light of our empirical results. The closest existing work is Carroll et al. (2009), who focus on the effect of present bias when switching costs are immediate but the benefits of making an active choice are delayed. In both their framework

\footnotetext{
${ }^{14}$ Both strategies rely on the assumption of uncorrelated measurement error, which may not be fully satisfied in our context given the multiple measures for a given behavioral parameter use the same questioning structure.
} 
and ours, the closer the default is to the optimal saving rate, the likelier it is that employees will procrastinate on making an active choice.

This story can partially rationalize our findings. When the default contribution rate is $0 \%$, the default is so undesirable that even procrastinators will be motivated to make a change. When the default is raised to $3 \%$ under auto-enrollment, present bias becomes a relevant individual characteristic that separates those who are willing to go the extra length for optimal savings versus those who are satisfied that $3 \%$ is "good enough". We note that what constitutes an "undesirable" default is not clear in our model, and that it would be possible to make the opposite prediction regarding opt-in vs. auto-enrollment. Our model also predicts that present bias will again be irrelevant if the default is too high rather than too low.

Our findings suggest that this narrative ought to be supplemented with financial literacy. Those who are financially illiterate are more likely to have no clear understanding of what a good saving rate is, and may therefore be more strongly influenced by the default. This is especially true if they interpret it as an endorsement from their employer and a signal of the optimal behavior (McKenzie et al., 2006). We find that low financial literacy becomes an important predictor of default behavior and total contributions in the opt-in regime, as more financially literate employees - even those exhibiting present bias - know to move away from a $0 \%$ contribution rate. In general, our model predicts that financial literacy becomes more relevant the more the default moves into the tails of employee's beliefs over the optimal savings rate. It is plausible that financial literacy would remain insignificant at moderate default levels (e.g. 5 or $6 \%$ ), but would again matter as the default increased further.

There have been several other mechanisms posited as motivations for the default effect that we have not considered here, including loss aversion (Kahneman and Tversky, 1979), and procrastination due to choice overload (Iyengar and Lepper, 2000). Loss aversion is likely to increase adherence to the default regardless of regime, provided that employees encode the default as the reference point, although models of expectations-based reference-dependence would not make any prediction here (Kőszegi and Rabin, 2006). Likewise, choice overload may play a role in choosing the default but would not seem to be able to explain the difference in default behavior under the two regimes. The number and range of fund choices was constant in our time period as far as we are aware. ${ }^{15}$

\footnotetext{
${ }^{15}$ In our survey we included the question, "In general, when you are shopping or ordering a meal at a restaurant
} 


\section{Conclusion}

This paper directly assesses potential mechanisms for explaining observed saving choices in the context of a large U.S. employer's retirement savings plan. In particular, we examine the role that long-run discount rates, present bias, financial literacy, and exponential-growth bias have in explaining whether employees make active contribution choices, respond to match incentives and take full advantage of tax-preferred saving vehicles and how the influence of these factors may vary based on a key feature of the choice environment, the default contribution rate.

The results provide new evidence that present bias plays a more important role under autoenrollment whereas financial literacy plays a more important role under an opt-in regime. Under auto-enrollment, more present bias (i.e. lower Beta), is associated with a higher likelihood of remaining at the default, lower contributions, and a lower probability of being at the annual cap. Under the opt-in regime, higher financial literacy is associated with a lower likelihood of remaining at the default, higher contributions, and a higher probability of being at the annual cap. Further, there is evidence that the influence of these factors is statistically different across default regime.

Our findings suggest that both present bias and financial illiteracy are potential mechanisms for the "default effect", which has been shown to be important in retirement savings plans. The key insight from our findings - and from our conceptual model - is that the precise mechanism driving the default effect can differ based on the default contribution rate that is set. In particular, we find present bias to be an important mechanism for staying at the default in auto-enrollment regimes, while financial literacy appears to be a more important predictor in opt-in default environments. These results suggest that the characteristics of those who follow the default are not fixed but differ based on the underlying default and that how the default is set can have distributional implications. For instance, a causal interpretation of our results suggests that auto-enrollment increases saving primarily among those with financial literacy.

We caution care when directly applying these results to other employment situations. The sample is particularly well educated and with commensurately high pay. In addition the employer is do you like menus with many different options or do you prefer menus with just a few options?" This was meant to proxy for a tendency to be overloaded by expansive choice. Including it in the regressions in Table 3 we found that it was only statistically significant "At/Above Max Match" for the auto-enrollment regime $(p<0.05)$ and it was negative in this case. Although tantalizing, the question had not been validated as a measure of propensity for choice overload, and the measure was not robustly associated with saving behavior. In this paper we focus on the results for which we have greater confidence. 
the Federal Government which constitutes a work environment that may differ in important ways from work environments in the private sector, such as different lengths of tenure and separation probabilities. That said, our findings suggest that developing ways to mitigate present bias and improve financial literacy may change saving outcomes and ultimately improve welfare. Importantly, our results suggest that interventions may need to vary based on terms of the default. Identifying potential interventions remains an important area for future research. 


\section{References}

Ameriks, John, Andrew Caplin, and John Leahy, "Wealth Accumulation and the Propensity to Plan," Quarterly Journal of Economics, August 2003, 118 (3), 1007-1047.

Ariely, Dan, George Loewenstein, and Drazen Prelec, "Coherent Arbitrariness: Stable Demand Curves without Stable Preferences," Quarterly Journal of Economics, 2003, 118 (1).

Beshears, John, James J. Choi, David Laibson, and Brigitte C. Madrian, "The Importance of Default Options for Retirement Savings Outcomes: Evidence from the United States," in "Social Security Policy in a Changing Environment," Chicago, IL: University of Chicago Press, 2009.

Brown, Jeffrey and Alessandro Previtero, "Procrastination, Present-Biased Preferences, and Financial Behaviors," August 2014. Working Paper.

Butt, Adam, M Scott Donald, F Douglas Foster, Susan Thorp, and Geoffrey J Warren, "One Size Fits All? Tailoring Retirement Plan Defaults," Journal of Economic Behavior E Organization, 2018, $145,546-566$.

Carroll, Gabriel D., James J. Choi, David Laibson, Brigitte C. Madrian, and Andrew Mertrick, "Optimal Defaults and Active Decisions," Quarterly Journal of Economics, 2009, 124 (4), 1639-74.

Chetty, Raj, John Friedman, Soren Leth-Petersen, Torben Nielsen, and Tore Olsen, "Active vs. Passive Decisions and Crowd-Out in Retirement Savings Accounts: Evidence from Denmark," Quarterly Journal of Economics, 2014, 129 (3), 1141-1219.

Choi, James J., David Laibson, Brigitte C. Madrian, and Andrew Metrick, "For Better or For Worse: Default Effect and 401(k) Savings Behavior," in David A. Wise, ed., Perspectives in the Economics of Aging, Chicago, IL: University of Chicago Press, 2004.

Falk, Armin, Anke Becker, Thomas Dohmen, David Huffman, and Uwe Sunde, "An Experimentally-Validated Survey Module of Economic Preferences," February 2014. Working Paper.

${ }_{-},{ }_{-},{ }_{-}$, and $\ldots$, "The Preference Survey Module: A Validated Instrument for Measuring Risk, Time, and Social Preferences," January 2016. IZA DP No. 9674.

Gillen, Ben, Erik Snowberg, and Leeat Yariv, "Experimenting with Measurement Error: Techniques with Applications to the Caltech Cohort Study," Working Paper, June 2017.

Goda, Gopi Shah and Colleen Flaherty Manchester, "Incorporating Employee Heterogeneity into Default Rules for Retirement Plan Selection," Journal of Human Resources, 2013, 48 (1), 198-235.

_ , Matthew Levy, Colleen Flaherty Manchester, Aaron Sojourner, and Joshua Tasoff, "Predicting Retirement Savings Using Survey Measures of Exponential-Growth Bias and Present Bias," Economic Inquiry, 2019, 57 (3), 1636-1658. 
Heutel, Garth, David Bradford, Charles Courtemanche, Patrick McAlvanah, and Christopher Ruhm, "Time Preferences and Consumer Behavior," July 2014. NBER Working Paper 20320.

Hung, Angela A., Andrew M. Parker, and Joanne K. Yoong, "Defining and Measuring Financial Literacy," September 2009. RAND Labor and Population Working Paper Series.

Iyengar, Sheena S and Mark R Lepper, "When Choice is Demotivating: Can One Desire Too Much of a Good Thing?," Journal of personality and social psychology, 2000, 79 (6), 995.

Kahneman, Daniel and Amos Tversky, "Prospect Theory: An Analysis of Decision under Risk," Econometrica, 1979, 47 (2), 263-291.

Köszegi, Botond and Matthew Rabin, "A Model of Reference-Dependent Preferences," Quarterly Journal of Economics, 2006, 121 (4), 1133-1165.

Laibson, David, "Golden Eggs and Hyperbolic Discounting," Quarterly Journal of Economics, 1997, 62 (2), 443-477.

Levy, Matthew R. and Joshua Tasoff, "Exponential Growth Bias and Lifecycle Consumption," Journal of the European Economic Association, 2016, 14 (3).

Lusardi, Annamaria and Olivia Mitchell, "Financial Literacy and Retirement Preparedness: Evidence and Implications for Financial Education," Business Economics, 2007, 42 (1), 35-44.

_ and Olivia S. Mitchell, "Planning and Financial Literacy: How Do Women Fare?," American Economic Review, 2011, 98 (2), 413-417.

_ and _, "The Economic Importance of Financial Literacy: Theory and Evidence," Journal of Economic Literature, March 2014, 52 (1), 5-44.

_ , Pierre-Carl Michaud, and Olivia Mitchell, "Optimal Financial Knowledge and Wealth Inequality," Journal of Political Economy, 2017, 125 (2), 431-477.

Madrian, Brigitte C. and Dennis F. Shea, "The Power of Suggestion: Inertia in 401(k) Participation and Savings Behavior," Quarterly Journal of Economics, 2001, 116 (4), 1149-1525.

McKenzie, Craig R.M., Michael J. Liersch, and Stacey R. Finkelstein, "Recommendations Implicit in Policy Defaults," Psychological Science, 2006, 17, 414-420.

O'Donoghue, Ted and Matthew Rabin, "Doing It Now or Later," American Economic Review, March 1999, $89(1), 103-124$.

_ and _, "Procrastination in Preparing for Retirement," in Henry Aaron, ed., Behavioral Dimensions of Retirement Economics, Brookings Institution Press \& Russell Sage Foundation, 1999, pp. 125-156.

_ and _ , "Choice and Procrastination," Quarterly Journal of Economics, 2001, 116 (1), 121-160.

Phelps, Edmund S and Robert A Pollak, "On Second-Best National Saving and Game-Equilibrium Growth," Review of Economic Studies, 1968, 35 (2), 185-199. 
Rooij, Maarten Van and Federica Teppa, "Personal traits and individual choices: Taking action in economic and non-economic decisions," Journal of Economic Behavior $\&$ Organization, 2014, 100, 33-43.

Stango, Victor and Jonathan Zinman, "Exponential Growth Bias and Household Finance," Journal of Finance, December 2009, 64 (6), 2807-2849.

_ , Joanne Yoong, and Jonathan Zinman, "Quicksand or Bedrock for Behavioral Economics? Assessing Foundational Empirical Questions," July 2017. NBER Working Paper 23625.

Sunstein, Cass R, "Nudges that Fail," Behavioural Public Policy, 2017, 1 (1), 4-25.

Tversky, Amos and Daniel Kahneman, "Judgment under uncertainty: Heuristics and biases," in "Utility, probability, and human decision making," Springer, 1975, pp. 141-162. 
Appendix A Additional Tables and Figures 
Table A.1: Correlation Matrix

\begin{tabular}{|c|c|c|c|c|c|c|c|c|c|c|}
\hline & Mean Alpha & Alpha 1 & Alpha 2 & Alpha 3 & Mean Beta & Beta 1 & Beta 2 & Mean Delta & Delta 1 & Delta 2 \\
\hline Alpha 1 & $0.813^{* * *}$ & 1.000 & & & & & & & & \\
\hline Alpha 2 & $0.822^{* * *}$ & $0.533^{* * *}$ & 1.000 & & & & & & & \\
\hline Alpha 3 & $0.773^{* * *}$ & $0.401^{* * *}$ & $0.452^{* * *}$ & 1.000 & & & & & & \\
\hline Mean Beta & -0.016 & -0.015 & -0.025 & -0.002 & 1.000 & & & & & \\
\hline Beta 1 & -0.025 & -0.018 & -0.035 & -0.013 & $0.866^{* * *}$ & 1.000 & & & & \\
\hline Beta 2 & 0.009 & 0.000 & 0.008 & 0.017 & $0.561^{* * *}$ & $0.072^{* *}$ & 1.000 & & & \\
\hline Mean Delta & 0.034 & 0.023 & 0.004 & 0.053 & $-0.466^{* * *}$ & $-0.446^{* * *}$ & $-0.192^{* * *}$ & 1.000 & & \\
\hline Delta 1 & 0.020 & 0.014 & -0.002 & 0.037 & $-0.500^{* * *}$ & $-0.632^{* * *}$ & 0.048 & $0.874^{* * *}$ & 1.000 & \\
\hline Delta 2 & 0.039 & 0.027 & 0.009 & $0.055^{*}$ & $-0.285^{* * *}$ & $-0.099^{* * *}$ & $-0.405^{* * *}$ & $0.835^{* * *}$ & $0.463^{* * *}$ & 1.000 \\
\hline Observations & 1396 & & & & & & & & & \\
\hline
\end{tabular}

${ }^{*} \mathrm{p}<0.10,{ }^{* *} \mathrm{p}<0.05,{ }^{* * *} \mathrm{p}<0.01$. 
Table A.2: Differences in Outcomes and Control Variables by Survey Response

\begin{tabular}{|c|c|c|c|c|c|c|c|}
\hline \multirow{3}{*}{ Outcome Variables. } & \multicolumn{3}{|c|}{ Survey Responders } & \multicolumn{3}{|c|}{ "Survey Non-Responders } & \multirow{2}{*}{$\begin{array}{l}\text {-test } \\
\text { Diff. }\end{array}$} \\
\hline & Obs. & Mean & Std. Dev. & Obs. & Mean & Std. Dev. & \\
\hline & & & & & & & \\
\hline At Default & 1,396 & 0.12 & 0.32 & 3,843 & 0.15 & 0.36 & $-0.03^{* * *}$ \\
\hline Passive & 651 & 0.12 & 0.32 & 1,719 & 0.18 & 0.38 & $-0.06^{* * *}$ \\
\hline At $0 \%$ & 1,396 & 0.07 & 0.25 & 3,843 & 0.10 & 0.29 & $-0.03^{* * *}$ \\
\hline TSP Amount (\$/year) & 1,396 & 7023.61 & 6047.51 & 3,843 & 5932.55 & 5517.60 & $1091.07^{* * *}$ \\
\hline TSP Rate & 1,396 & 7.70 & 5.67 & 3,843 & 6.51 & 5.21 & $1.19^{* * *}$ \\
\hline At/Above Max. Match & 1,396 & 0.60 & 0.49 & 3,843 & 0.58 & 0.49 & 0.02 \\
\hline \multirow{2}{*}{\multicolumn{8}{|c|}{ Individual Characteristics: }} \\
\hline & & & & & & & \\
\hline Total Pay & 1,396 & 86437.89 & 32253.08 & 3,843 & 85970.58 & 31422.28 & 467.31 \\
\hline Age 1 ay & 1,396 & 47.32 & 10.82 & $\begin{array}{l}3,843 \\
3,843\end{array}$ & 45.70 & 10.66 & $1.61^{* * *}$ \\
\hline Tenure in Years & 1,396 & 8.77 & $\begin{array}{l}10.02 \\
7.87\end{array}$ & $\begin{array}{l}2,045 \\
3,843\end{array}$ & 9.17 & 8.21 & $\begin{array}{l}1.01 \\
-0.40\end{array}$ \\
\hline Eligible for Catch-Up Contributions & 1,396 & 0.46 & 0.50 & 3,843 & 0.38 & 0.49 & $0.07^{* * *}$ \\
\hline \multicolumn{8}{|l|}{ Highest Education: } \\
\hline High School & 1,396 & 0.16 & 0.37 & 3,843 & 0.20 & 0.40 & $-0.03^{* * *}$ \\
\hline Some College or Associate & 1,396 & 0.16 & 0.37 & 3,843 & 0.15 & 0.36 & 0.01 \\
\hline Bachelor & 1,396 & 0.40 & 0.49 & 3,843 & 0.41 & 0.49 & -0.01 \\
\hline Post Bachelor & 1,396 & 0.28 & 0.45 & 3,843 & 0.24 & 0.43 & $0.03^{* *}$ \\
\hline \multicolumn{8}{|l|}{ Race/Ethnicity: } \\
\hline White & 1,396 & 0.71 & 0.45 & 3,843 & 0.64 & 0.48 & $0.07^{* * *}$ \\
\hline Hispanic & 1,396 & 0.05 & 0.21 & 3,843 & 0.06 & 0.23 & $-0.01^{*}$ \\
\hline Black & 1,396 & 0.20 & 0.40 & $\begin{array}{l}0,045 \\
3,843\end{array}$ & 0.25 & 0.43 & $-0.06^{* * *}$ \\
\hline \multirow{2}{*}{\multicolumn{8}{|c|}{$\begin{array}{l}\text { Uther Race } \\
\text { Gender: }\end{array}$}} \\
\hline & & & & & & & \\
\hline Female & 1,396 & 0.55 & 0.50 & 3,843 & 0.58 & 0.49 & $-0.03^{*}$ \\
\hline \multirow{2}{*}{\multicolumn{8}{|c|}{ Work Location: }} \\
\hline & & & & & & & \\
\hline $\begin{array}{l}\mathrm{DC} \\
\mathrm{MD}\end{array}$ & 1,396 & 0.26 & 0.44 & 3,843 & 0.28 & 0.45 & -0.02 \\
\hline $\mathrm{MD}$ & 1,396 & 0.09 & 0.29 & 3,843 & 0.09 & & 0.00 \\
\hline PA & 1,396 & 0.29 & 0.46 & 3,843 & 0.24 & 0.43 & $0.05^{* * *}$ \\
\hline VA & 1,396 & 0.05 & 0.21 & 3,843 & 0.07 & 0.25 & $-0.02^{* * *}$ \\
\hline \multirow{2}{*}{\multicolumn{8}{|c|}{ Job Position: }} \\
\hline & & & & & & & \\
\hline $\begin{array}{l}\text { Non-Supervisory } \\
\text { Team Leader }\end{array}$ & $\begin{array}{l}1,396 \\
1,396\end{array}$ & $\begin{array}{l}0.87 \\
0.03\end{array}$ & $\begin{array}{l}0.34 \\
0.18\end{array}$ & $\begin{array}{l}3,843 \\
3,843\end{array}$ & $\begin{array}{l}0.87 \\
0.03\end{array}$ & $\begin{array}{l}0.34 \\
0.17\end{array}$ & $\begin{array}{c}-0.00 \\
0.00\end{array}$ \\
\hline Supervisor or Manager & 1,396 & 0.10 & 0.30 & 3,843 & 0.10 & 0.30 & -0.00 \\
\hline $\mathrm{N}$ & 1,396 & & & 3,843 & & & 5,239 \\
\hline
\end{tabular}

${ }^{*} \mathrm{p}<0.10,{ }^{* *} \mathrm{p}<0.05,{ }^{* * *} \mathrm{p}<0.01$. 
Table A.3: Differences in Covariates across Enrollment Regime by Bandwidth

\begin{tabular}{|c|c|c|c|c|c|c|c|c|c|c|c|c|c|c|c|c|}
\hline $\begin{array}{l}\text { Total Pay (S/year) } \\
\text { Age }\end{array}$ & 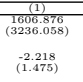 & 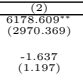 & 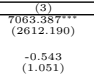 & 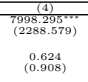 & 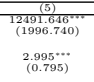 & 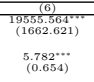 & 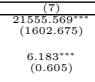 & 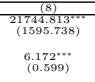 & 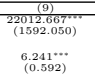 & 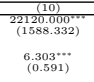 & 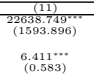 & 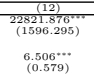 & 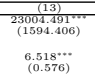 & 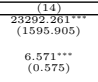 & 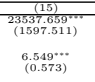 & 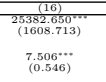 \\
\hline Tenure in Years & 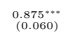 & $\begin{array}{l}1.76 \% \ldots \\
(0.077)\end{array}$ & $\begin{array}{l}2,280 \cdots \\
(0.092)\end{array}$ & (3.499\% & $\begin{array}{l}4.795 \cdots \\
(0.122)\end{array}$ & $\begin{array}{l}6.611 \cdots \cdots \\
(0.122)\end{array}$ & $\begin{array}{l}7.335 . \cdots \\
(0.19)\end{array}$ & $\begin{array}{l}7.441 \cdots \cdots \\
(0.121)\end{array}$ & $\begin{array}{l}7.635 \cdots \\
(0.126)\end{array}$ & 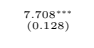 & $\begin{array}{l}7.930 \cdots \\
(0.135) \\
7.135)\end{array}$ & $\begin{array}{l}8.0739 . \\
(0.139)\end{array}$ & $\begin{array}{l}8.153 \cdots \\
(0.142)\end{array}$ & $\begin{array}{l}8,241 \cdots \\
(0.146)\end{array}$ & $\begin{array}{l}8.319 \cdots \\
(0.199)\end{array}$ & 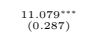 \\
\hline $\begin{array}{l}\text { Highest Education } \\
\quad \text { High School }\end{array}$ & $\begin{array}{l}-0.0 .044 \\
(0.056)\end{array}$ & ) & 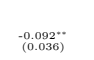 & 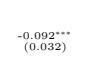 & 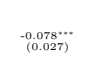 & (0.005) & $\left.\begin{array}{c}0.0 .08 \\
(0.0211\end{array}\right)$ & $\frac{0.0 .06}{(0.021)}$ & $\frac{0.055}{(0.021)}$ & $\frac{0.055}{(0.021)}$ & 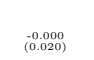 & $\frac{0.0 .05}{(0.020)}$ & $\frac{0.0 .03}{(0.020)}$ & $\frac{0.0 .03}{(0.020)}$ & $\frac{0.0 .04}{(0.020)}$ & 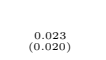 \\
\hline Some College or Associate & ${ }^{-0.047}$ & $\left.\begin{array}{l}0.013 \\
(0.037)\end{array}\right)$ & $\begin{array}{l}0.0202 \\
(0.032)\end{array}$ & $\begin{array}{l}0.072 \cdot \cdots \\
(0.0299)\end{array}$ & 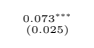 & 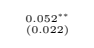 & $\frac{0.0366^{\circ}}{(0.021)}$ & $\begin{array}{l}0.039^{\circ} \\
(0.021)\end{array}$ & 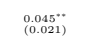 & 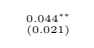 & 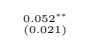 & 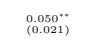 & 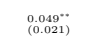 & 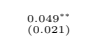 & $\begin{array}{l}0.0511 .1 \\
0.0221)\end{array}$ & 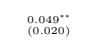 \\
\hline Bachelor & $\begin{array}{l}0.028 \\
(0.069)\end{array}$ & $\begin{array}{l}0.047 \\
0.0 .053)\end{array}$ & 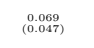 & $\begin{array}{l}0.077^{\circ} \\
(0.041)\end{array}$ & $\begin{array}{c}0.0936 \\
(0.033)\end{array}$ & 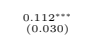 & 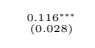 & 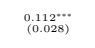 & 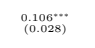 & 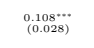 & 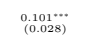 & $\begin{array}{l}0.095 \% \\
(0.027) \\
(0.027)\end{array}$ & $\begin{array}{l}0.095 \% \\
(0.027) \\
(0.027)\end{array}$ & 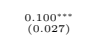 & 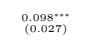 & $\begin{array}{l}0.090 \cdots \\
(0.026)\end{array}$ \\
\hline Post Bachelor & $\begin{array}{l}0.072 \\
(0.065)\end{array}$ & $\begin{array}{l}\left.\frac{0.008}{(0.050)}\right) \\
(0.050\end{array}$ & 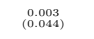 & (0.0.056 & 势 & 势 & 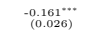 & 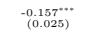 & 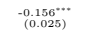 & 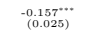 & 势 & 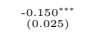 & 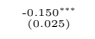 & 年 & 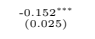 & 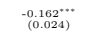 \\
\hline 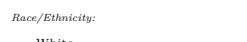 & & & & & & & & & & & & & & & & \\
\hline white & ${ }^{-0.022}$ & $\frac{-0.032}{\left({ }^{(0.048)}\right.}$ & $\frac{(0.038}{(0.042)}$ & $\frac{-0.012}{\left(0_{0.037)}\right.}$ & $\begin{array}{l}\left.\frac{0.004}{(0.032)}\right) \\
(0.03)\end{array}$ & $\begin{array}{l}0.028 \\
(0.027)\end{array}$ & $\begin{array}{l}0.027 \\
(0.026)\end{array}$ & 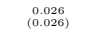 & 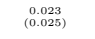 & 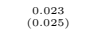 & $\underset{\substack{0.0222 \\
(0.025)}}{(0.0)}$ & $\frac{0.0 .15}{(0.025)}$ & $\underset{\substack{0.0 .11 \\
(0.025)}}{2}$ & $\frac{0.011}{(0.025)}$ & 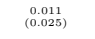 & 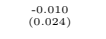 \\
\hline Hispanic & $\begin{array}{l}0.019 \\
(0.027)\end{array}$ & $\begin{array}{l}\frac{0.022}{(0.022)} \\
(0.02\end{array}$ & $\begin{array}{l}0.016 \\
(0.021)\end{array}$ & $\begin{array}{l}\frac{0.007}{(0.018)} \\
(0.07\end{array}$ & $\begin{array}{l}\frac{0.000}{(0.016)} \\
(0.06)\end{array}$ & $\frac{-0.001}{(0.013)}$ & $\frac{-0.000}{(0.012)}$ & $\frac{-0.001}{(0.012)}$ & $\begin{array}{l}0.000 \\
(0.012)\end{array}$ & $\frac{-0.000}{(0.012)}$ & $\begin{array}{l}0.000 \\
(0.012)\end{array}$ & $\left.\begin{array}{l}0.001 \\
(0.012)\end{array}\right)$ & $\begin{array}{l}0.000 \\
(0.012)\end{array}$ & $\frac{-0.000}{(0.012)}$ & $\begin{array}{l}-0.001 \\
(0.012)\end{array}$ & $\underbrace{-0.03}_{(0.0011)}$ \\
\hline Black & $\begin{array}{l}-0.036 \\
(0.050)\end{array}$ & $\begin{array}{l}\left.\frac{0.006}{(0.041)}\right) \\
(0.04\end{array}$ & $\begin{array}{l}(. .019 \\
(0.035)\end{array}$ & $\begin{array}{l}-0.003 \\
(0.031)\end{array}$ & $\int_{(0.021}^{-0.027)}$ & $\begin{array}{l}-0.034 \\
(0.023)\end{array}$ & $\frac{-0.033}{(0.022)}$ & $\begin{array}{l}-0.0302 \\
(0.022)\end{array}$ & $\begin{array}{l}-0.029 \\
(0.022)\end{array}$ & ${ }^{-0.022}$ & $\begin{array}{l}-0.026 \\
(0.022)\end{array}$ & $\underbrace{-0.022}(0.022)$ & $\underbrace{-0.017}_{(0.017)}$ & $\frac{-0.015}{(0.022)}$ & $\begin{array}{l}-0.015 \\
(0.022)\end{array}$ & $\begin{array}{l}0.009 \\
(0.021)\end{array}$ \\
\hline $\begin{array}{l}\text { Other Race } \\
\text { Work Location: }\end{array}$ & $\begin{array}{l}0.039 \\
(0.027)\end{array}$ & $\begin{array}{l}\left.\frac{0.005}{(0.023)}\right) \\
(0.02\end{array}$ & $\begin{array}{l}\substack{0.012 \\
(0.021)} \\
0\end{array}$ & $\begin{array}{l}0.007) \\
(0.018)\end{array}$ & $\begin{array}{l}0.017 \\
(0.017)\end{array}$ & $\begin{array}{l}0.007 \\
(0.013)\end{array}$ & $\begin{array}{l}0.007 \\
(0.012)\end{array}$ & $\begin{array}{l}0.005 \\
(0.012)\end{array}$ & $\begin{array}{l}0.005 \\
(0.012)\end{array}$ & $\begin{array}{l}0.006 \\
(0.012)\end{array}$ & $\begin{array}{l}\left.\frac{0.005}{(0.012)}\right) \\
(0.02)\end{array}$ & $\begin{array}{l}\left.\frac{0.005}{(0.012)}\right) \\
(0.02)\end{array}$ & $\begin{array}{l}\left.\frac{0.005}{(0.02)}\right) \\
(0.02)\end{array}$ & 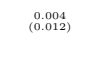 & 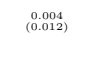 & $\begin{array}{l}\substack{0.001 \\
(0.011)} \\
(0.11)\end{array}$ \\
\hline DC & ${ }^{-0.028}$ & $\begin{array}{l}0.001 \\
(0.047)\end{array}$ & $\begin{array}{l}-0.028 \\
(0.042)\end{array}$ & $\begin{array}{l}-0.064^{*} \\
(0.036)\end{array}$ & $\begin{array}{c}-.082 \cdots \\
(0.031)\end{array}$ & $\begin{array}{l}-0.106 \cdots \\
(0.025)\end{array}$ & $\begin{array}{l}-0.106 \cdots \\
(0.023)\end{array}$ & $\begin{array}{l}-0.102 \cdots \\
(0.023)\end{array}$ & $\begin{array}{l}-0.088 \cdots \\
(0.023)\end{array}$ & $\begin{array}{l}-.088 \% \cdots \\
(0.023)\end{array}$ & $\begin{array}{l}-0.080 \cdots \\
(0.023)\end{array}$ & $\left.\begin{array}{l}-.074 \ldots \\
(0.023)\end{array}\right)$ & $\begin{array}{l}-.0 .06 \% \cdots \\
(0.024)\end{array}$ & 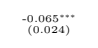 & $\begin{array}{l}-0.063 \% \\
(0.023)\end{array}$ & ${ }^{-0.009}$ \\
\hline MD & ${ }^{-0.021}$ & $\begin{array}{l}\substack{0.002 \\
\left({ }^{0.026)}\right)} \\
0\end{array}$ & $\begin{array}{l}0.0 .16 \\
(0.025)\end{array}$ & $\frac{0.015}{(0.022)}$ & $\frac{-0.008}{(0.0199)}$ & $\begin{array}{l}0.051 \% \\
(0.020) \\
0.050\end{array}$ & ( & ( & 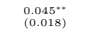 & $\begin{array}{l}\substack{0.0433 \\
(0.018)} \\
(0.18)\end{array}$ & 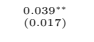 & $\begin{array}{l}0.037 .7 \\
(0.017)\end{array}$ & 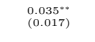 & $\begin{array}{l}0.034 . \\
(0.0127)\end{array}$ & $\begin{array}{l}0.035 .7 \\
(0.0127)\end{array}$ & $\begin{array}{l}0.0 .17 \\
(0.015)\end{array}$ \\
\hline PA & $\begin{array}{l}0.089 \\
(0.066)\end{array}$ & $\frac{-0.018}{(0.053)}$ & $\begin{array}{l}-0.029 \\
(0.046)\end{array}$ & $\begin{array}{l}0.012 \\
(0.040)\end{array}$ & $\begin{array}{l}0.009 \\
(0.036)\end{array}$ & $-\frac{0.038}{(0.028)}$ & $\frac{-0.030}{(0.026)}$ & $\begin{array}{l}-0.024 \\
(0.026)\end{array}$ & $\begin{array}{l}-0.019 \\
(0.026)\end{array}$ & $\begin{array}{l}-0.016 \\
(0.026)\end{array}$ & $\frac{-0.009}{(0.026)}$ & $\begin{array}{l}-0.012 \\
(0.026)\end{array}$ & $\begin{array}{l}-0.014 \\
(0.026)\end{array}$ & $\begin{array}{l}-0.014 \\
(0.026)\end{array}$ & $\begin{array}{l}-0.016 \\
(0.026)\end{array}$ & ${ }^{-0.0 .27}$ \\
\hline va & $\begin{array}{l}0.0397 \\
(0.037)\end{array}$ & $\frac{0.0 .17}{(0.023)}$ & 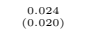 & $\begin{array}{l}0.0 .07 \\
(0.016)\end{array}$ & ) & (0.005) & $\frac{0.005}{(0.0122)}$ & $\frac{0.0 .04}{(0.012)}$ & 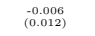 & 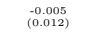 & 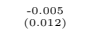 & $\frac{0.0 .069}{(0.0122)}$ & $\frac{0.0 .04}{(0.012)}$ & (0.005) & $\frac{0.005}{(0.012)}$ & 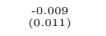 \\
\hline Other Location & $\begin{array}{l}-0.079 \\
(0.067)\end{array}$ & $\underbrace{-0.001}_{-0.001}$ & 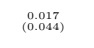 & $\begin{array}{l}0.0 .39 \\
(0.039)\end{array}$ & $\begin{array}{l}0.090 \cdots \\
(0.034)\end{array}$ & $\begin{array}{l}0.097 \cdots \\
(0.029)\end{array}$ & ( & $\begin{array}{l}0.081 \cdots \\
(0.027) \\
(0.027)\end{array}$ & 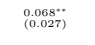 & 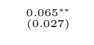 & $\begin{array}{l}0.055 .7 \\
(0.026)\end{array}$ & $\begin{array}{l}0.055 . \\
(0.026)\end{array}$ & 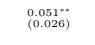 & $\begin{array}{l}\frac{0.050}{0.056)} \\
(0.026)\end{array}$ & $\begin{array}{l}0.0 .00^{\circ} \\
(0.026)\end{array}$ & $\begin{array}{l}\left.\frac{0.027}{(0.025)}\right) \\
(0.02\end{array}$ \\
\hline Job Positition: & & & & & & & & & & & & & & & & \\
\hline Non-Supervisory & ${ }^{-0.069}$ & $\frac{(0.043)}{(0.034)}$ & $\begin{array}{l}-0.061 \\
(0.032)\end{array}$ & ${ }^{-0.036}(0.027)$ & ( & $\begin{array}{l}-0.081 \% \\
(0.019)\end{array}$ & $\begin{array}{l}-0.08 \% 1 \\
(0.018)\end{array}$ & $\begin{array}{l}-0.094 .6 \\
(0.018)\end{array}$ & 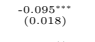 & ( & 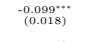 & $\begin{array}{l}-0.0101 .1 \\
(0.018)\end{array}$ & $\begin{array}{l}-0.103 .1 \\
(0.018)\end{array}$ & $\begin{array}{l}-0.0106 \\
(0.018)\end{array}$ & $\begin{array}{l}-0.0106 \\
(0.018)\end{array}$ & $\begin{array}{l}-0.1237 \\
(0.017)\end{array}$ \\
\hline Team Leader & $\begin{array}{l}0.008 \\
(0.024)\end{array}$ & $\begin{array}{l}\left.\frac{0.018}{(0.017)}\right) \\
(0.7)\end{array}$ & 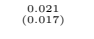 & $\begin{array}{l}0.011 \\
(0.013)\end{array}$ & $\begin{array}{l}0.011 \\
(0.012)\end{array}$ & 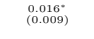 & 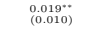 & 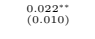 & 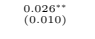 & 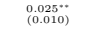 & 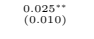 & 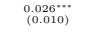 & 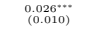 & 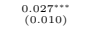 & 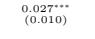 & 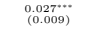 \\
\hline Supervisoor or Manager & $\begin{array}{l}0.061 \\
(0.039)\end{array}$ & $\begin{array}{c}0.0 .05 \\
(0.030)\end{array}$ & $\begin{array}{l}0.0 .00 \\
(0.028)\end{array}$ & $\begin{array}{l}0.025 \\
(0.024)\end{array}$ & 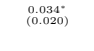 & 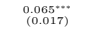 & (0.016) & 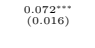 & 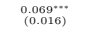 & $\begin{array}{l}0.07110 \\
(0.016)\end{array}$ & 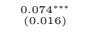 & $\begin{array}{l}0.075 .6 \\
(0.016)\end{array}$ & $\begin{array}{l}0.0776) \\
(0.016)\end{array}$ & (0.076) & $\begin{array}{l}0.070 . \\
(0.016)\end{array}$ & 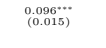 \\
\hline $\begin{array}{l}\text { Gender: } \\
\text { Female }\end{array}$ & $\begin{array}{l}-0.0 .099 \\
(0.070)\end{array}$ & (0.050) & $\frac{0.0 .24}{(0.088)}$ & $\frac{0.0 .012}{(0.042)}$ & $\frac{0.0 .021}{(0.037)}$ & 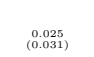 & $\begin{array}{c}0.0 .08) \\
(0.0299)\end{array}$ & (0.025) & 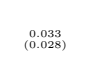 & $\left(\begin{array}{l}0.0 .055 \\
(0.028)\end{array}\right.$ & $\frac{0.0 .06}{(0.028)}$ & $\left(\begin{array}{l}0.0 .028) \\
(0.028)\end{array}\right.$ & $\left(\begin{array}{l}0.0 .03 \\
(0.028)\end{array}\right.$ & $\frac{0.0 .00}{(0.028)}$ & $\begin{array}{l}0.0 .372 \\
0.0288\end{array}$ & 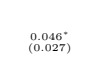 \\
\hline Male & $\begin{array}{l}0.089 \\
(0.070)\end{array}$ & $\frac{\substack{0.001 \\
(0.055)}}{(0.05}$ & $\begin{array}{l}-0.024 \\
(0.0018)\end{array}$ & $\begin{array}{l}0.012 \\
(0.042)\end{array}$ & $\begin{array}{l}0.021 \\
(0.037)\end{array}$ & $\begin{array}{l}-0.025 \\
(0.031)\end{array}$ & $\begin{array}{l}-0.028 \\
(0.029)\end{array}$ & ${ }^{-0.025}$ & $\frac{-0.033}{(0.028)}$ & ${ }^{-0.035}$ & $\begin{array}{l}-0.036 \\
(0.0285)\end{array}$ & $\begin{array}{l}-0.042 \\
(0.028)\end{array}$ & $\begin{array}{l}-0.043 \\
(0.028)\end{array}$ & $\begin{array}{l}-0.049 \\
(0.028)\end{array}$ & $\begin{array}{l}-0.037 \\
(0.028)\end{array}$ & $\begin{array}{l}-0.0 .466^{\circ} \\
(0.027)\end{array}$ \\
\hline $\begin{array}{l}\text { Time Preferences } \\
\text { Extreme Impatience }\end{array}$ & & & & & & & & & & & & & & & & \\
\hline Extreme Patience & $\begin{array}{l}(0.053) \\
-0.028 \\
0.054\end{array}$ & 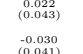 & $\begin{array}{l}\text { (.0.037) } \\
-0.0371\end{array}$ & 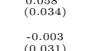 & $\begin{array}{l}\underbrace{(0.030)}_{0.039} \\
-0.005\end{array}$ & $\begin{array}{l}(.0225) \\
0.0250\end{array}$ & $\begin{array}{l}.0 .07) \\
(0.024) \\
-0.000\end{array}$ & $\begin{array}{c}(.0023) \\
0.001\end{array}$ & $\begin{array}{l}\frac{6.003}{(0.023)} \\
0.004\end{array}$ & $\begin{array}{c}0.004 \\
(0.023) \\
0.001\end{array}$ & $\begin{array}{l}0.0 .03 \\
(0.023) \\
-0.004\end{array}$ & $\begin{array}{c}\underbrace{}_{0.0233} \\
-0.007\end{array}$ & 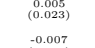 & $\begin{array}{l}\substack{0.005 \\
(0.023)} \\
-0.009\end{array}$ & $\begin{array}{l}\frac{0.003}{(0.023)} \\
-0.005\end{array}$ & $\begin{array}{c}-.0 .022 \\
-0.003\end{array}$ \\
\hline Truat in Fed. Gov. as Employer & $\begin{array}{l}-0.003 \\
(0.140)\end{array}$ & $\begin{array}{l}(0.041) \\
\text {-0.079 } \\
(0.0108)\end{array}$ & $\begin{array}{l}-0.0369 \\
-0.099 \\
(0.098)\end{array}$ & $\begin{array}{l}-0.031) \\
-0.103 \\
(0.083)\end{array}$ & 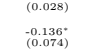 & 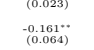 & 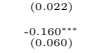 & $\begin{array}{l}(0.021) \\
-0.156 \cdots \\
(0.059)\end{array}$ & 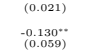 & 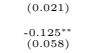 & 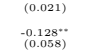 & 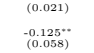 & 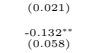 & 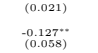 & 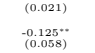 & 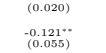 \\
\hline $\begin{array}{l}\text { Eligible for Catch-Up Contributions } \\
\text { Bandedith }\end{array}$ & 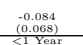 & 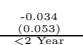 & 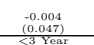 & 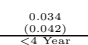 & 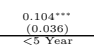 & 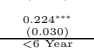 & 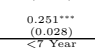 & 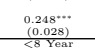 & 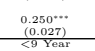 & 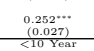 & 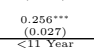 & 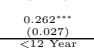 & 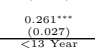 & 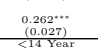 & 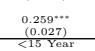 & 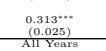 \\
\hline Observations & 206 & 341 & ${ }_{439}$ & 559 & ${ }_{727}$ & 10011 & 1195 & 1209 & 1231 & 1238 & 1258 & $\begin{array}{r}1270 \\
\end{array}$ & 1276 & 1282 & $\begin{array}{l}12887 \\
\end{array}$ & $\begin{array}{l}1396 \\
1396\end{array}$ \\
\hline
\end{tabular}

${ }^{*} \mathrm{p}<0.10,{ }^{* *} \mathrm{p}<0.05,{ }^{* * *} \mathrm{p}<0.01$. 
Figure A.1: Robustness of Relationship between Alpha, Beta, Delta, Fin Lit and TSP Outcomes by Sample Selection

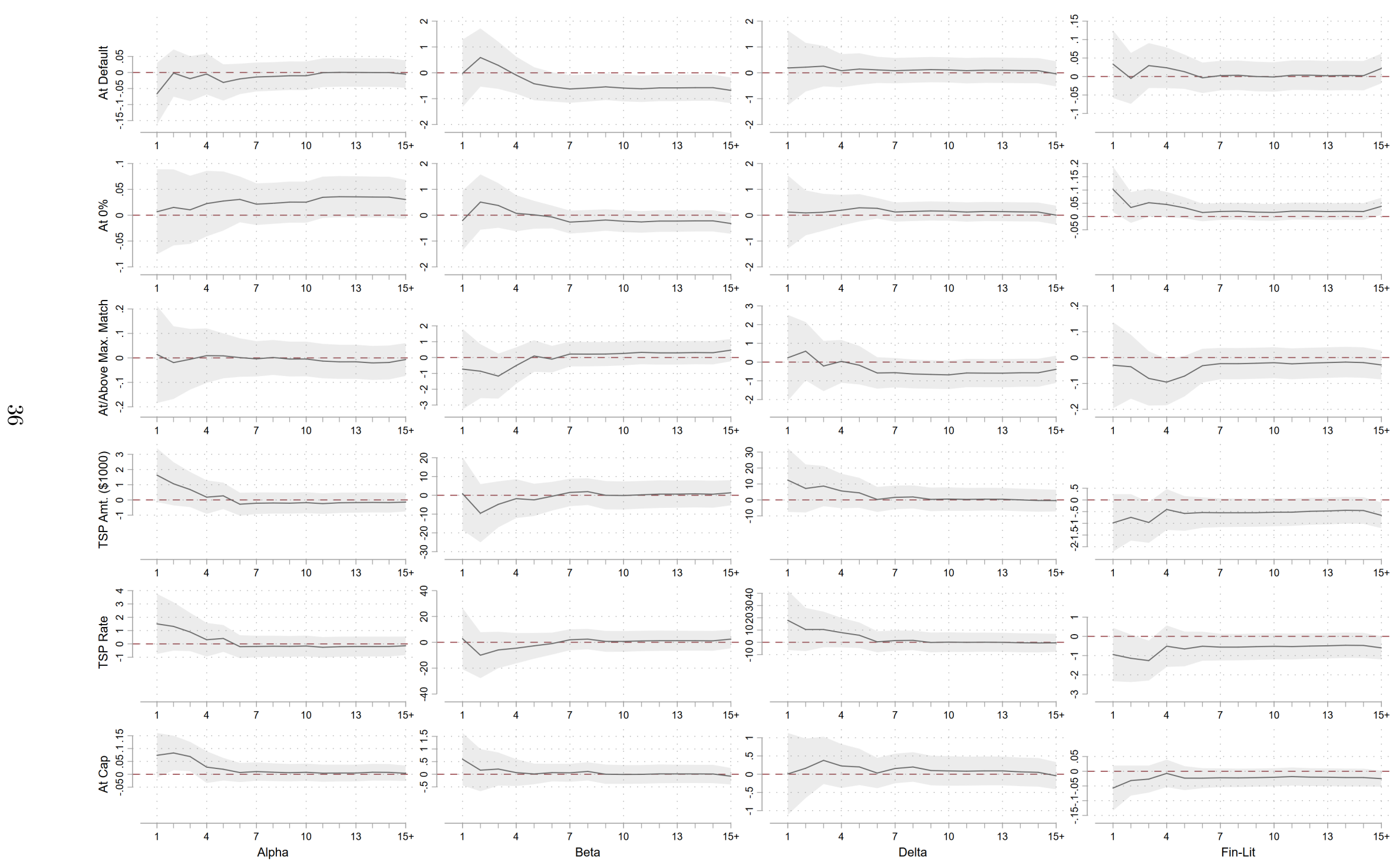




\section{Appendix B Additional Robustness}

Unlike the administrative outcomes, there is reason to believe that our survey measures are subject to measurement error. Including multiple elicitations in our survey, however, provides us with two possible strategies for overcoming this.

The first strategy is simply to average the multiple measures and conduct OLS analysis using the mean value as a regressor, which we do in our main results. Under the assumption that our multiple measures of each characteristic are in fact noisy measures of a "true" characteristic and that the errors in the multiple measures are uncorrelated, then it follows trivially that the level of measurement error will be reduced but not eliminated by taking the means. As a result, using a mean value should yield less-biased results in OLS than using a single measure.

The second strategy is to use an obviously-related instrumental variables (ORIV) approach (Gillen et al., 2017). A standard approach to dealing with a variable measured with noise is the use of an instrument uncorrelated with that noise. A second survey measure, provided the measurement error is uncorrelated, can provide such an instrument. However, experimenters often lack a theory for which survey measure should be the regressor and which the instrument. The ORIV solution is to use all measures simultaneously as regressors and as instruments for one another. That is, the true model is given by $Y=\alpha+\gamma X^{*}$, but the econometrician only has noisy measures $X^{i}=X^{*}+\nu_{i}$ for $i=1,2$ with $\nu_{1}$ and $\nu_{2}$ uncorrelated. One estimates the model:

$$
\left(\begin{array}{c}
Y \\
Y
\end{array}\right)=\left(\begin{array}{c}
\alpha_{1} \\
\alpha_{2}
\end{array}\right)+\gamma\left(\begin{array}{c}
X^{1} \\
X^{2}
\end{array}\right) \text {, instrumenting }\left(\begin{array}{c}
X^{1} \\
X^{2}
\end{array}\right) \text { with } W=\left(\begin{array}{cc}
X^{2} & 0 \\
0 & X^{1}
\end{array}\right)
$$

Gillen, Snowberg and Yariv (2017) prove that ORIV produces consistent estimates of $\gamma$ (Proposition 1), and that the estimated standard errors, when clustered by subject, are consistent estimates of the asymptotic standard errors (Proposition 2).

While we can adapt this two-measure approach to our multiple-measure, multiple-outcome setting straightforwardly, the method places stronger demands on the relationships between the multiple measures. We therefore first determine for which parameters the ORIV approach is appropriate to allow us to utilize our data in a more efficient manner than the OLS approach. 
Table B.1: Fitting TSP Contributions with OLS and IV specifications of Alpha, Beta and Delta

\begin{tabular}{|c|c|c|c|c|c|c|c|c|}
\hline Alpha & $\begin{array}{c}(1) \\
\text { TSP Amt. } \\
241.433 \\
(162.996)\end{array}$ & $\begin{array}{c}(2) \\
\text { TSP Amt. } \\
372.352 \\
(238.102)\end{array}$ & $\begin{array}{c}(3) \\
\text { TSP Amt. } \\
220.227 \\
(162.376)\end{array}$ & $\begin{array}{c}(4) \\
\text { TSP Amt. } \\
235.337 \\
(160.800)\end{array}$ & $\begin{array}{c}(5) \\
\text { TSP Amt. } \\
338.052 \\
(239.206)\end{array}$ & $\begin{array}{c}(6) \\
\text { TSP Amt. } \\
362.846 \\
(236.448)\end{array}$ & $\begin{array}{c}(7) \\
\text { TSP Amt. } \\
229.665 \\
(164.071)\end{array}$ & $\begin{array}{c}(8) \\
\text { TSP Amt. } \\
335.520 \\
(239.333)\end{array}$ \\
\hline Beta & $\begin{array}{l}3112.273^{*} \\
(1749.142)\end{array}$ & $\begin{array}{c}2916.644 \\
(1782.480)\end{array}$ & $\begin{array}{c}-7000.387^{*} \\
(4253.092)\end{array}$ & $\begin{array}{c}7588.194^{* * *} \\
(2878.184)\end{array}$ & $\begin{array}{l}-6670.476 \\
(4425.536)\end{array}$ & $\begin{array}{c}6822.387^{* *} \\
(2865.446)\end{array}$ & $\begin{array}{c}882.684 \\
(10232.182)\end{array}$ & $\begin{array}{c}-7078.366^{* *} \\
(3052.475)\end{array}$ \\
\hline Delta & $\begin{array}{c}5442.307^{* * *} \\
(1770.302)\end{array}$ & $\begin{array}{c}4898.211^{* * *} \\
(1792.739)\end{array}$ & $\begin{array}{c}771.762 \\
(2563.737)\end{array}$ & $\begin{array}{c}15594.640^{* * *} \\
(5526.162)\end{array}$ & $\begin{array}{c}493.037 \\
(2652.354)\end{array}$ & $\begin{array}{c}13763.381^{* *} \\
(5430.897)\end{array}$ & $\begin{array}{c}8116.707^{* * *} \\
(2627.694)\end{array}$ & $\begin{array}{c}628.479 \\
(3396.843)\end{array}$ \\
\hline Fin Lit (z-score) & $\begin{array}{c}398.412^{* * *} \\
(147.599)\end{array}$ & $\begin{array}{c}417.092^{* * *} \\
(151.975)\end{array}$ & $\begin{array}{c}419.327^{* * *} \\
(146.612)\end{array}$ & $\begin{array}{r}358.674^{* *} \\
(150.263)\end{array}$ & $\begin{array}{c}454.502^{* * *} \\
(152.137)\end{array}$ & $\begin{array}{c}380.361^{* *} \\
(155.759)\end{array}$ & $\begin{array}{c}389.059^{* * *} \\
(146.613)\end{array}$ & $\begin{array}{c}455.113^{* * *} \\
(152.032)\end{array}$ \\
\hline Some College or Associate & $\begin{array}{l}223.067 \\
(431.107)\end{array}$ & $\begin{array}{c}180.332 \\
(439.787)\end{array}$ & $\begin{array}{c}290.738 \\
(427.517)\end{array}$ & $\begin{array}{c}37.394 \\
(444.885)\end{array}$ & $\begin{array}{c}239.469 \\
(439.154)\end{array}$ & $\begin{array}{c}29.817 \\
(454.643)\end{array}$ & $\begin{array}{c}166.644 \\
(432.525)\end{array}$ & $\begin{array}{c}236.212 \\
(440.262)\end{array}$ \\
\hline Bachelor & $\begin{array}{c}1546.979^{* * *} \\
(387.523)\end{array}$ & $\begin{array}{c}1561.848^{* * *} \\
(394.440)\end{array}$ & $\begin{array}{c}1574.383^{* * *} \\
(387.853)\end{array}$ & $\begin{array}{c}1374.681^{* * *} \\
(400.048)\end{array}$ & $\begin{array}{c}1567.536^{* * *} \\
(398.907)\end{array}$ & $\begin{array}{c}1414.572^{* * *} \\
(408.855)\end{array}$ & $\begin{array}{c}1479.641^{* * *} \\
(397.315)\end{array}$ & $\begin{array}{c}1561.159^{* * *} \\
(401.466)\end{array}$ \\
\hline Post-Bachelor & $\begin{array}{c}1864.409^{* * *} \\
(464.051)\end{array}$ & $\begin{array}{c}1892.487^{* * *} \\
(472.507)\end{array}$ & $\begin{array}{c}1895.699^{* * *} \\
(464.570)\end{array}$ & $\begin{array}{c}1666.820^{* * *} \\
(477.933)\end{array}$ & $\begin{array}{c}1900.734^{* * *} \\
(477.439)\end{array}$ & $\begin{array}{c}1729.527^{* * *} \\
(488.385)\end{array}$ & $\begin{array}{c}1787.129^{* * *} \\
(471.476)\end{array}$ & $\begin{array}{c}1893.797^{* * *} \\
(481.944)\end{array}$ \\
\hline White & $\begin{array}{l}-1054.786 \\
(733.512)\end{array}$ & $\begin{array}{l}-962.220 \\
(726.473)\end{array}$ & $\begin{array}{r}-1107.770 \\
(732.587)\end{array}$ & $\begin{array}{l}-1132.516 \\
(725.348)\end{array}$ & $\begin{array}{l}-995.696 \\
(731.424)\end{array}$ & $\begin{array}{l}-1045.729 \\
(726.355)\end{array}$ & $\begin{array}{l}-1112.823 \\
(725.503)\end{array}$ & $\begin{array}{l}-1001.556 \\
(735.110)\end{array}$ \\
\hline Hispanic & $\begin{array}{l}-1508.655 \\
(933.820)\end{array}$ & $\begin{array}{l}-1373.347 \\
(920.782)\end{array}$ & $\begin{array}{l}-1459.035 \\
(938.160)\end{array}$ & $\begin{array}{c}-1661.870^{*} \\
(921.952)\end{array}$ & $\begin{array}{r}-1309.657 \\
(934.138)\end{array}$ & $\begin{array}{c}-1520.968^{*} \\
(918.440)\end{array}$ & $\begin{array}{c}-1557.847^{*} \\
(921.658)\end{array}$ & $\begin{array}{l}-1312.504 \\
(935.905)\end{array}$ \\
\hline Black & $\begin{array}{c}-2960.119^{* * *} \\
(784.820)\end{array}$ & $\begin{array}{c}-2808.053^{* * *} \\
(780.737)\end{array}$ & $\begin{array}{c}-3027.083^{* * * *} \\
(787.027)\end{array}$ & $\begin{array}{c}-2964.340^{* * *} \\
(776.506)\end{array}$ & $\begin{array}{c}-2832.225^{* * *} \\
(790.063)\end{array}$ & $\begin{array}{c}-2828.438^{* * *} \\
(780.650)\end{array}$ & $\begin{array}{c}-2990.396^{* * *} \\
(775.880)\end{array}$ & $\begin{array}{c}-2834.634^{* * * *} \\
(791.559)\end{array}$ \\
\hline Male & $\begin{array}{l}-307.417 \\
(286.443)\end{array}$ & $\begin{array}{l}-353.678 \\
(289.078)\end{array}$ & $\begin{array}{l}-334.741 \\
(284.454)\end{array}$ & $\begin{array}{l}-444.422 \\
(297.443)\end{array}$ & $\begin{array}{l}-382.378 \\
(289.494)\end{array}$ & $\begin{array}{l}-468.341 \\
(301.059)\end{array}$ & $\begin{array}{l}-381.749 \\
(302.323)\end{array}$ & $\begin{array}{l}-389.369 \\
(295.715)\end{array}$ \\
\hline Eligible for Catch-Up Contributions & $\begin{array}{c}1622.838^{* * *} \\
(496.767)\end{array}$ & $\begin{array}{c}1670.439^{* * *} \\
(502.544)\end{array}$ & $\begin{array}{c}1790.502^{* * *} \\
(506.388)\end{array}$ & $\begin{array}{c}1477.956^{* * *} \\
(501.868)\end{array}$ & $\begin{array}{c}1837.290^{* * *} \\
(517.587)\end{array}$ & $\begin{array}{c}1544.159^{* * * *} \\
(510.599)\end{array}$ & $\begin{array}{c}1627.425^{* * *} \\
(508.818)\end{array}$ & $\begin{array}{c}1841.727^{* * *} \\
(514.913)\end{array}$ \\
\hline Constant & $\begin{array}{c}-10268.373^{* * *} \\
(3597.886)\end{array}$ & $\begin{array}{c}-10001.982^{* * *} \\
(3648.651)\end{array}$ & $\begin{array}{l}4206.733 \\
(6527.565)\end{array}$ & $\begin{array}{c}-23091.519^{* * *} \\
(7569.896)\end{array}$ & $\begin{array}{c}3690.322 \\
(6775.863)\end{array}$ & $\begin{array}{c}-21200.378^{* * *} \\
(7481.982)\end{array}$ & $\begin{array}{l}-10016.591 \\
(11131.179)\end{array}$ & $\begin{array}{c}4016.233 \\
(5403.506)\end{array}$ \\
\hline $\begin{array}{l}\text { Alpha } \\
\text { Beta } \\
\text { Delta }\end{array}$ & $\begin{array}{l}\text { OLS } \\
\text { OLS } \\
\text { OLS }\end{array}$ & $\begin{array}{l}\text { IV } \\
\text { OLS } \\
\text { OLS }\end{array}$ & $\begin{array}{l}\text { OLS } \\
\text { IV } \\
\text { OLS }\end{array}$ & $\begin{array}{l}\text { OLS } \\
\text { OLS } \\
\text { IV }\end{array}$ & $\begin{array}{l}\text { IV } \\
\text { IV } \\
\text { OLS }\end{array}$ & $\begin{array}{l}\text { IV } \\
\text { OLS } \\
\text { IV }\end{array}$ & $\begin{array}{l}\text { OLS } \\
\text { IV } \\
\text { IV }\end{array}$ & $\begin{array}{l}\text { IV } \\
\text { IV } \\
\text { IV }\end{array}$ \\
\hline $\begin{array}{l}\text { F-Stat Alpha } \\
\text { F-Stat Beta } \\
\text { F-Stat Delta }\end{array}$ & & 516.891 & 25.703 & 39.361 & $\begin{array}{c}259.637 \\
11.912\end{array}$ & $\begin{array}{c}263.291 \\
19.995\end{array}$ & $\begin{array}{c}2.613 \\
184.166\end{array}$ & $\begin{array}{c}177.537 \\
58.988 \\
158.650\end{array}$ \\
\hline $\begin{array}{l}\text { Mean DV } \\
\text { R-squared } \\
\text { Observations }\end{array}$ & $\begin{array}{c}7023.61 \\
.374 \\
1396\end{array}$ & $\begin{array}{c}7031.85 \\
.365 \\
4029\end{array}$ & $\begin{array}{c}7023.61 \\
.349 \\
2792\end{array}$ & $\begin{array}{c}7023.61 \\
.338 \\
2792\end{array}$ & $\begin{array}{c}7031.85 \\
.343 \\
8058\end{array}$ & $\begin{array}{c}7031.85 \\
.388 \\
8058\end{array}$ & $\begin{array}{c}7023.61 \\
.366 \\
2792\end{array}$ & $\begin{array}{c}7031.85 \\
.341 \\
16116\end{array}$ \\
\hline
\end{tabular}

Notes: Standard errors in parentheses and clustered on ID. Dependent variables as indicated in column heading.

All specifications also include controls for pay, pay squared, age, age squared, years of tenure, years of tenure squared, Work Location, Job Position and Trust in Fed. Gov. as Employer.

${ }^{*} \mathrm{p}<0.10,{ }^{* *} \mathrm{p}<0.05, * * * \mathrm{p}<0.01$. 
In Table B.1, we regress TSP contribution levels on our survey measures and other controls, considering all possible permutations of OLS and ORIV for Alpha, Beta, and Delta. The outcome in all eight columns is annual TSP contributions in dollars, as of April 2017. Column (1) is the most straightforward to interpret, being an OLS regression using the mean values of Alpha, Beta, and Delta as well as the standard controls. Both Beta and Delta are strongly related to TSP contributions, with estimated coefficients of $\$ 3,112$ and $\$ 5,442$ and significant at the 10 and 1 percent levels, respectively. This implies a one standard deviation increase in Beta is associated with $\$ 280$ higher annual contributions, and a one standard deviation increase in Delta is associated with $\$ 490$ higher annual contributions. These results are comparable to the $\$ 398$ increase associated with a one standard deviation increase in our measure of general financial literacy, which is significant at the 1 percent level. The coefficient on Alpha is somewhat smaller at $\$ 241$ and is also not statistically significant.

The remaining columns of Table B.1 attempt to use the ORIV strategy, first for one measure at a time, then two, then all three in Column (8). Which measures are instrumented are indicated in the rows immediately below the coefficient estimates. When only Alpha is instrumented in Column (2), the coefficient increases from $\$ 241$ to $\$ 372$, but remains just shy of statistical significance at conventional levels. Delta is instrumented in Column (4), which almost triples its estimated coefficient to $\$ 15,595$ and it remains highly statistically significant. Unusually, when Beta is instrumented in Column (3), the coefficient becomes large and changes sign $(-\$ 7,000)$ becoming marginally significant. This occurs because our two Beta measures are not strong predictors of one another. Whereas the multiple Alpha measures are all correlated with each other with correlations above 0.4, and the two Delta measures correlated at 0.45, our two Beta measures are correlated only at 0.09 (a full correlation matrix is available in Appendix A). This is because we compute Beta by dividing one time preference elicitation by another. ${ }^{16}$ Attempting ORIV for Beta thus results in a weak instruments problem, suggesting that the technique is not appropriate for that measure.

Given that ORIV is not appropriate for Beta, the full ORIV approach shown in Column (8) is also not appropriate. Instead, the next best approach, and our preferred specification, is to

\footnotetext{
${ }^{16}$ The present-future staircase $(\mathrm{PF})$ allows us to compute a measure of (Beta $\mathrm{x}$ Delta) $P F$. The future-future staircase $(\mathrm{FF})$ allows us to compute a measure of Delta $F F$. We obtain Beta by dividing Beta $\mathrm{x}$ Delta from the present-future staircase by the Delta from the future-future staircase: Beta $=(\text { Beta } \mathrm{x} \text { Delta })_{P F} /$ Delta $_{F F}$. Both the numerator and the denominator are likely to have measurement error, creating more noise in our measures of Beta.
} 
use ORIV for Alpha and Delta, and simply use the arithmetic mean of Beta. This is shown in Column (6) of Table B.1. The results are reassuringly similar to the preceding columns. The coefficient on Alpha remains economically meaningful at $\$ 363$ and not quite statistically significant. The coefficients on Beta and Delta are both large, at $\$ 7,588$ and $\$ 13,763$, respectively, and both significant at the 5 percent level. It is also worth noting that the coefficient on the general financial literacy score remains large and statistically significant at $\$ 380 .^{17}$

We replicate Tables 3 and 4 using ORIV with the preferred specification from Column (6) of Table B.1, instrumenting for Alpha and Delta and averaging our two measures of Beta. Comparing Tables 3 and 4 to Tables B.2 and B.3, the coefficients are slightly larger in magnitude using ORIV, but the main implications are the same. Financial literacy is statistically significant in predicting default enrollment, non-participation and annual contributions under the opt-in regime and Beta is statistically significant in predicting passive choice, being at the default, annual TSP contributions and contributing the annual maximum under auto-enrollment. In addition, the predicted effect of Beta on following the default is significantly different across regimes as is the predicted effect of financial literacy on TSP contribution amount. The one coefficient that is no longer significant is the effect of Beta on maximum match under opt-in. In Table 4 the coefficient was significant and negative, surprisingly implying that more patience leads to less use of the maximum match. Once we correct for measurement error in this way, this association disappears, suggesting lack of robustness.

\footnotetext{
${ }^{17}$ We provide first-stage results for the specifications in Column (6) and Column (8) in B.4.
} 
Table B.2: Relationship between Alpha, Beta and Delta with TSP Outcomes (Default, Passive, 0\%, Max Match) - OLS/IV Prediction

\begin{tabular}{|c|c|c|c|c|c|c|c|}
\hline & $\begin{array}{c}(1) \\
\text { At Default }\end{array}$ & $\begin{array}{c}(2) \\
\text { At Default }\end{array}$ & $\begin{array}{c}(3) \\
\text { Passive }\end{array}$ & $\begin{array}{l}(4) \\
\text { At } 0 \%\end{array}$ & $\begin{array}{l}(5) \\
\text { At } 0 \%\end{array}$ & $\begin{array}{c}\text { At/Above } \\
\text { Max. Match }\end{array}$ & $\begin{array}{c}\text { (7) } \\
\text { At/Above Max. Match }\end{array}$ \\
\hline Alpha & $\begin{array}{l}-0.026 \\
(0.016)\end{array}$ & $\begin{array}{l}-0.029 \\
(0.027)\end{array}$ & $\begin{array}{l}-0.001 \\
(0.024)\end{array}$ & $\begin{array}{l}-0.026 \\
(0.016)\end{array}$ & $\begin{array}{l}0.020 \\
(0.023)\end{array}$ & $\begin{array}{c}0.012 \\
(0.030)\end{array}$ & $\begin{array}{l}-0.016 \\
(0.042)\end{array}$ \\
\hline Beta & $\begin{array}{c}0.224 \\
(0.222)\end{array}$ & $\begin{array}{l}-0.554^{*} \\
(0.332)\end{array}$ & $\begin{array}{l}-0.371 \\
(0.314)\end{array}$ & $\begin{array}{c}0.224 \\
(0.222)\end{array}$ & $\begin{array}{l}-0.167 \\
(0.212)\end{array}$ & $\begin{array}{l}-0.453 \\
(0.392)\end{array}$ & $\begin{array}{l}-0.368 \\
(0.438)\end{array}$ \\
\hline Delta & $\begin{array}{l}0.150 \\
(0.371)\end{array}$ & $\begin{array}{l}-0.079 \\
(0.627)\end{array}$ & $\begin{array}{l}0.195 \\
(0.605)\end{array}$ & $\begin{array}{l}0.150 \\
(0.371)\end{array}$ & $\begin{array}{l}-0.075 \\
(0.391)\end{array}$ & $\begin{array}{l}0.014 \\
(0.705)\end{array}$ & $\begin{array}{l}-1.173 \\
(0.874)\end{array}$ \\
\hline Fin Lit (z-score) & $\begin{array}{c}-0.031 * * \\
(0.014)\end{array}$ & $\begin{array}{l}-0.012 \\
(0.016)\end{array}$ & $\begin{array}{l}-0.013 \\
(0.014)\end{array}$ & $\begin{array}{c}-0.031^{* *} \\
(0.014)\end{array}$ & $\begin{array}{c}0.010 \\
(0.010)\end{array}$ & $\begin{array}{c}0.003 \\
(0.020)\end{array}$ & $\begin{array}{l}-0.022 \\
(0.022)\end{array}$ \\
\hline Some College or Associate & $\begin{array}{l}0.008 \\
(0.047)\end{array}$ & $\begin{array}{l}-0.027 \\
(0.060)\end{array}$ & $\begin{array}{c}-0.114^{* *} \\
(0.055)\end{array}$ & $\begin{array}{c}0.008 \\
(0.047)\end{array}$ & $\begin{array}{c}0.009 \\
(0.046)\end{array}$ & $\begin{array}{c}0.014 \\
(0.062)\end{array}$ & $\begin{array}{l}-0.017 \\
(0.079)\end{array}$ \\
\hline Bachelor & $\begin{array}{c}-0.096^{* *} \\
(0.039)\end{array}$ & $\begin{array}{l}-0.005 \\
(0.053)\end{array}$ & $\begin{array}{l}-0.056 \\
(0.051)\end{array}$ & $\begin{array}{c}-0.096^{* *} \\
(0.039)\end{array}$ & $\begin{array}{l}-0.044 \\
(0.034)\end{array}$ & $\begin{array}{l}0.100^{*} \\
(0.057)\end{array}$ & $\begin{array}{l}0.058 \\
(0.067)\end{array}$ \\
\hline Post-Bachelor & $\begin{array}{c}-0.115^{* * *} \\
(0.043)\end{array}$ & $\begin{array}{l}-0.027 \\
(0.053)\end{array}$ & $\begin{array}{l}-0.076 \\
(0.050)\end{array}$ & $\begin{array}{c}-0.115^{* * *} \\
(0.043)\end{array}$ & $\begin{array}{l}-0.044 \\
(0.038)\end{array}$ & $\begin{array}{l}0.105 \\
(0.068)\end{array}$ & $\begin{array}{c}0.035 \\
(0.070)\end{array}$ \\
\hline White & $\begin{array}{c}0.030 \\
(0.035)\end{array}$ & $\begin{array}{l}-0.027 \\
(0.061)\end{array}$ & $\begin{array}{c}0.062^{* *} \\
(0.026)\end{array}$ & $\begin{array}{l}0.030 \\
(0.035)\end{array}$ & $\begin{array}{l}-0.006 \\
(0.034)\end{array}$ & $\begin{array}{c}0.115 \\
(0.086)\end{array}$ & $\begin{array}{c}0.032 \\
(0.099)\end{array}$ \\
\hline Hispanic & $\begin{array}{l}0.041 \\
(0.053)\end{array}$ & $\begin{array}{l}-0.007 \\
(0.082)\end{array}$ & $\begin{array}{l}0.116^{*} \\
(0.063)\end{array}$ & $\begin{array}{c}0.041 \\
(0.053)\end{array}$ & $\begin{array}{l}-0.002 \\
(0.049)\end{array}$ & $\begin{array}{l}0.105 \\
(0.123)\end{array}$ & $\begin{array}{l}-0.130 \\
(0.135)\end{array}$ \\
\hline Black & $\begin{array}{c}0.091^{* *} \\
(0.041)\end{array}$ & $\begin{array}{l}0.006 \\
(0.071)\end{array}$ & $\begin{array}{c}0.121^{* * *} \\
(0.040)\end{array}$ & $\begin{array}{c}0.091^{* *} \\
(0.041)\end{array}$ & $\begin{array}{l}0.062 \\
(0.045)\end{array}$ & $\begin{array}{c}0.002 \\
(0.096)\end{array}$ & $\begin{array}{l}-0.146 \\
(0.107)\end{array}$ \\
\hline Male & $\begin{array}{c}0.062^{* * *} \\
(0.024)\end{array}$ & $\begin{array}{c}0.002 \\
(0.028)\end{array}$ & $\begin{array}{l}-0.009 \\
(0.027)\end{array}$ & $\begin{array}{c}0.066^{* * *} \\
(0.024)\end{array}$ & $\begin{array}{c}-0.038^{* *} \\
(0.017)\end{array}$ & $\begin{array}{l}-0.019 \\
(0.040)\end{array}$ & $\begin{array}{l}0.017 \\
(0.041)\end{array}$ \\
\hline Eligible for Catch-Up Contributions & $\begin{array}{l}-0.033 \\
(0.039)\end{array}$ & $\begin{array}{l}-0.045 \\
(0.053)\end{array}$ & $\begin{array}{l}-0.048 \\
(0.050)\end{array}$ & $\begin{array}{c}-0.033 \\
(0.039)\end{array}$ & $\begin{array}{c}-0.022 \\
(0.042)\end{array}$ & $\begin{array}{c}0.006 \\
(0.068)\end{array}$ & $\begin{array}{c}0.076 \\
(0.082)\end{array}$ \\
\hline Constant & $\begin{array}{r}-0.198 \\
(0.556) \\
\end{array}$ & $\begin{array}{l}1.414^{*} \\
(0.855) \\
\end{array}$ & $\begin{array}{r}0.806 \\
(0.819) \\
\end{array}$ & $\begin{array}{l}-0.198 \\
(0.556) \\
\end{array}$ & $\begin{array}{r}0.582 \\
(0.556) \\
\end{array}$ & $\begin{array}{r}1.507 \\
(1.095)\end{array}$ & $\begin{array}{r}0.826 \\
(1.154)\end{array}$ \\
\hline $\begin{array}{l}\text { Alpha } \\
\text { Beta } \\
\text { Delta }\end{array}$ & $\begin{array}{l}\text { IV } \\
\text { OLS } \\
\text { IV }\end{array}$ & $\begin{array}{l}\text { IV } \\
\text { OLS } \\
\text { IV }\end{array}$ & $\begin{array}{l}\text { OLS } \\
\text { OLS } \\
\text { OLS }\end{array}$ & $\begin{array}{l}\text { IV } \\
\text { OLS } \\
\text { IV }\end{array}$ & $\begin{array}{l}\text { IV } \\
\text { OLS } \\
\text { IV }\end{array}$ & $\begin{array}{l}\text { IV } \\
\text { OLS } \\
\text { IV }\end{array}$ & $\begin{array}{l}\text { IV } \\
\text { OLS } \\
\text { IV }\end{array}$ \\
\hline $\begin{array}{l}\text { Delta } \\
\text { F-Stat Alpha } \\
\text { F-Stat Delta }\end{array}$ & $\begin{array}{c}\text { IV } \\
171.386 \\
10.976\end{array}$ & $\begin{array}{c}\text { IV } \\
87.877 \\
7.340\end{array}$ & OLS & $\begin{array}{c}\text { IV } \\
171.386 \\
10.976\end{array}$ & $\begin{array}{c}\text { IV } \\
87.877 \\
7.340\end{array}$ & $\begin{array}{c}\text { IV } \\
171.386 \\
10.976\end{array}$ & $\begin{array}{c}\text { IV } \\
87.877 \\
7.340\end{array}$ \\
\hline Sample & Opt-In Regime & Auto-Enroll Regime & Auto-Enroll Regime & Opt-In Regime & Auto-Enroll Regime & Opt-In Regime & Auto-Enroll Regime \\
\hline $\begin{array}{l}p \text {-value for } \\
\text { Equality Across Groups } \\
\text { Alpha } \\
\text { Beta } \\
\text { Delta } \\
\text { Fin Lit } \\
\text { All Four }\end{array}$ & & $\begin{array}{l}0.932 \\
0.052 \\
0.753 \\
0.364 \\
0.049\end{array}$ & & & $\begin{array}{l}0.099 \\
0.204 \\
0.677 \\
0.016 \\
0.017\end{array}$ & & $\begin{array}{l}0.589 \\
0.885 \\
0.290 \\
0.391 \\
0.211\end{array}$ \\
\hline $\begin{array}{l}\text { Mean DV } \\
\text { R-squared } \\
\text { Cluster } \\
\text { Observations }\end{array}$ & $\begin{array}{c}.087 \\
0.083 \\
705 \\
4230\end{array}$ & $\begin{array}{c}.143 \\
0.093 \\
638 \\
3828\end{array}$ & $\begin{array}{c}0.116 \\
0.114 \\
629 \\
3774 \\
\end{array}$ & $\begin{array}{c}.087 \\
0.083 \\
705 \\
4230\end{array}$ & $\begin{array}{c}.047 \\
0.051 \\
638 \\
3828\end{array}$ & $\begin{array}{c}.613 \\
0.087 \\
705 \\
4230\end{array}$ & $\begin{array}{c}.58 \\
0.041 \\
638 \\
3828\end{array}$ \\
\hline
\end{tabular}

Robust standard errors reported, clustered on ID. Dependent variable in column heading. All specifications also include controls for Salary, Salary Squared, Age, Age Squared, Years of Tenure, Years of Tenure Squared, binary variables for Extreme Patience and Extreme Impatience, Work Location, Job Position, and Trust in Fed. Gov. as Employer. ${ }^{*} \mathrm{p}<0.10,{ }^{* *} \mathrm{p}<0.05,{ }^{* * *} \mathrm{p}<0.01$. 
Table B.3: Relationship between Alpha, Beta and Delta with TSP Outcomes (Amount, Rate, Cap) - OLS/IV Prediction

\begin{tabular}{|c|c|c|c|c|c|c|}
\hline & TSP Amt. & $\begin{array}{c}(2) \\
\text { TSP Amt. }\end{array}$ & $\begin{array}{l}\text { (3) } \\
\text { TSP Rate }\end{array}$ & TSP Rate & At Cap & At Cap \\
\hline Alpha & $\begin{array}{c}354.946 \\
(338.841)\end{array}$ & $\begin{array}{l}297.371 \\
(312.806)\end{array}$ & $\begin{array}{c}0.215 \\
(0.352)\end{array}$ & $\begin{array}{l}0.126 \\
(0.384)\end{array}$ & $\begin{array}{l}-0.008 \\
(0.018)\end{array}$ & $\begin{array}{l}0.010 \\
(0.013)\end{array}$ \\
\hline Beta & $\begin{array}{c}6002.750 \\
(4711.255)\end{array}$ & $\begin{array}{c}8615.256^{* * *} \\
(3203.928)\end{array}$ & $\begin{array}{l}4.285 \\
(4.653)\end{array}$ & $\begin{array}{l}8.371^{* *} \\
(3.657)\end{array}$ & $\begin{array}{c}0.375 \\
(0.261)\end{array}$ & $\begin{array}{l}0.290^{*} \\
(0.150)\end{array}$ \\
\hline Delta & $\begin{array}{l}12535.177 \\
(8399.065)\end{array}$ & $\begin{array}{c}15821.395^{* *} \\
(6855.822)\end{array}$ & $\begin{array}{l}11.635 \\
(8.298)\end{array}$ & $\begin{array}{l}15.362^{*} \\
(8.191)\end{array}$ & $\begin{array}{l}0.785 \\
(0.496)\end{array}$ & $\begin{array}{l}0.729^{* *} \\
(0.320)\end{array}$ \\
\hline Fin Lit (z-score) & $\begin{array}{c}681.084^{* * *} \\
(258.762)\end{array}$ & $\begin{array}{c}40.545 \\
(155.269)\end{array}$ & $\begin{array}{c}0.687^{* * *} \\
(0.242)\end{array}$ & $\begin{array}{c}0.116 \\
(0.216)\end{array}$ & $\begin{array}{l}0.027^{* *} \\
(0.012)\end{array}$ & $\begin{array}{c}0.001 \\
(0.008)\end{array}$ \\
\hline Some College or Associate & $\begin{array}{l}-443.609 \\
(700.204)\end{array}$ & $\begin{array}{c}6.670 \\
(543.772)\end{array}$ & $\begin{array}{l}-0.197 \\
(0.753)\end{array}$ & $\begin{array}{c}0.742 \\
(0.884)\end{array}$ & $\begin{array}{l}-0.048 \\
(0.033)\end{array}$ & $\begin{array}{l}-0.004 \\
(0.024)\end{array}$ \\
\hline Bachelor & $\begin{array}{c}1917.601^{* * * *} \\
(668.441)\end{array}$ & $\begin{array}{c}201.819 \\
(415.729)\end{array}$ & $\begin{array}{c}2.211^{* * *} \\
(0.715)\end{array}$ & $\begin{array}{l}0.482 \\
(0.555)\end{array}$ & $\begin{array}{l}0.021 \\
(0.034)\end{array}$ & $\begin{array}{l}-0.023 \\
(0.017)\end{array}$ \\
\hline Post-Bachelor & $\begin{array}{c}2929.466^{* * *} \\
(839.303)\end{array}$ & $\begin{array}{c}330.842 \\
(496.572)\end{array}$ & $\begin{array}{c}3.147^{* * *} \\
(0.851)\end{array}$ & $\begin{array}{c}0.550 \\
(0.690)\end{array}$ & $\begin{array}{c}0.029 \\
(0.044)\end{array}$ & $\begin{array}{l}0.002 \\
(0.017)\end{array}$ \\
\hline White & $\begin{array}{c}-335.843 \\
(1102.251)\end{array}$ & $\begin{array}{c}-1650.321^{*} \\
(945.432)\end{array}$ & $\begin{array}{c}-0.521 \\
(1.078)\end{array}$ & $\begin{array}{c}-1.660^{*} \\
(1.005)\end{array}$ & $\begin{array}{l}-0.112 \\
(0.074)\end{array}$ & $\begin{array}{c}0.023 \\
(0.046)\end{array}$ \\
\hline Hispanic & $\begin{array}{l}-1406.124 \\
(1352.929)\end{array}$ & $\begin{array}{l}-1301.084 \\
(1209.068)\end{array}$ & $\begin{array}{l}-1.751 \\
(1.335)\end{array}$ & $\begin{array}{l}-0.827 \\
(1.473)\end{array}$ & $\begin{array}{c}-0.241^{* * *} \\
(0.077)\end{array}$ & $\begin{array}{l}0.007 \\
(0.064)\end{array}$ \\
\hline Black & $\begin{array}{c}-2721.022^{* *} \\
(1205.010)\end{array}$ & $\begin{array}{c}-2579.215^{* *} \\
(1035.069)\end{array}$ & $\begin{array}{c}-2.839^{* *} \\
(1.176)\end{array}$ & $\begin{array}{c}-2.724^{* *} \\
(1.130)\end{array}$ & $\begin{array}{c}-0.187^{* *} \\
(0.080)\end{array}$ & $\begin{array}{c}0.032 \\
(0.045)\end{array}$ \\
\hline Male & $\begin{array}{l}-554.837 \\
(488.383)\end{array}$ & $\begin{array}{l}-342.832 \\
(340.827)\end{array}$ & $\begin{array}{l}-0.474 \\
(0.496)\end{array}$ & $\begin{array}{l}-0.275 \\
(0.449)\end{array}$ & $\begin{array}{l}-0.051^{*} \\
(0.028)\end{array}$ & $\begin{array}{l}-0.002 \\
(0.016)\end{array}$ \\
\hline Eligible for Catch-Up Contributions & $\begin{array}{c}2566.852^{* * * *} \\
(773.768)\end{array}$ & $\begin{array}{l}-581.359 \\
(658.512)\end{array}$ & $\begin{array}{c}2.206^{* * *} \\
(0.767)\end{array}$ & $\begin{array}{c}0.309 \\
(0.852)\end{array}$ & $\begin{array}{l}0.066 \\
(0.046)\end{array}$ & $\begin{array}{l}0.005 \\
(0.034)\end{array}$ \\
\hline Constant & $\begin{array}{c}-24656.380^{*} \\
(12790.360) \\
\end{array}$ & $\begin{array}{c}-19548.919^{* *} \\
(8784.881) \\
\end{array}$ & $\begin{array}{c}-14.982 \\
(12.693) \\
\end{array}$ & $\begin{array}{r}-17.217^{*} \\
(10.146) \\
\end{array}$ & $\begin{array}{c}-1.653^{* *} \\
(0.750) \\
\end{array}$ & $\begin{array}{c}-1.064^{* *} \\
(0.420) \\
\end{array}$ \\
\hline $\begin{array}{l}\text { Alpha } \\
\text { Beta } \\
\text { Delta }\end{array}$ & $\begin{array}{l}\text { IV } \\
\text { OLS } \\
\text { IV }\end{array}$ & $\begin{array}{l}\text { IV } \\
\text { OLS } \\
\text { IV }\end{array}$ & $\begin{array}{l}\text { IV } \\
\text { OLS } \\
\text { IV }\end{array}$ & $\begin{array}{l}\text { IV } \\
\text { OLS } \\
\text { IV }\end{array}$ & $\begin{array}{l}\text { IV } \\
\text { OLS } \\
\text { IV }\end{array}$ & $\begin{array}{l}\text { IV } \\
\text { OLS } \\
\text { IV }\end{array}$ \\
\hline $\begin{array}{l}\text { F-Stat Alpha } \\
\text { F-Stat Delta }\end{array}$ & $\begin{array}{l}171.386 \\
10.976\end{array}$ & $\begin{array}{l}87.877 \\
7.340\end{array}$ & $\begin{array}{l}171.386 \\
10.976\end{array}$ & $\begin{array}{l}87.877 \\
7.340\end{array}$ & $\begin{array}{l}171.386 \\
10.976\end{array}$ & $\begin{array}{l}87.877 \\
7.340\end{array}$ \\
\hline Sample & Opt-In Regime & Auto-Enroll Regime & Opt-In Regime & Auto-Enroll Regime & Opt-In Regime & Auto-Enroll Regime \\
\hline $\begin{array}{l}p \text {-value for } \\
\text { Equality Across Groups } \\
\text { Alpha } \\
\text { Beta } \\
\text { Delta } \\
\text { Fin Lit } \\
\text { All Four }\end{array}$ & & $\begin{array}{l}0.901 \\
0.647 \\
0.762 \\
0.034 \\
0.321\end{array}$ & & $\begin{array}{l}0.865 \\
0.490 \\
0.749 \\
0.078 \\
0.469\end{array}$ & & $\begin{array}{l}0.440 \\
0.776 \\
0.924 \\
0.078 \\
0.448\end{array}$ \\
\hline $\begin{array}{l}\text { Mean DV } \\
\text { R-squared } \\
\text { Cluster } \\
\text { Observations }\end{array}$ & $\begin{array}{c}8685.865 \\
0.252 \\
705 \\
4230\end{array}$ & $\begin{array}{c}5204.147 \\
0.400 \\
638 \\
3828\end{array}$ & $\begin{array}{l}8.702 \\
0.125 \\
705 \\
4230\end{array}$ & $\begin{array}{c}6.632 \\
0.065 \\
638 \\
3828\end{array}$ & $\begin{array}{l}.129 \\
0.116 \\
705 \\
4230\end{array}$ & $\begin{array}{c}.042 \\
0.063 \\
638 \\
3828 \\
\end{array}$ \\
\hline
\end{tabular}

Robust standard errors reported, clustered on ID. Dependent variable in column heading. All specifications also include controls for Salary, Salary Squared, Age, Age Squared, Years of Tenure, Years of Tenure Squared, binary variables for Extreme Patience and Extreme Impatience, Work Location, Job Position, and Trust in Fed. Gov. as Employer. ${ }^{*} \mathrm{p}<0.10,{ }^{* *} \mathrm{p}<0.05$, $^{* *} \mathrm{p}<0.01$. 
Table B.4: First Stage for Column (6), Table 1

\begin{tabular}{lcc}
\hline \hline & $(1)$ & $(2)$ \\
& Alpha & Delta \\
\hline IV Alpha 1 & $0.307^{* * *}$ & 0.000 \\
& $(0.013)$ & $(0.001)$ \\
& & \\
IV Alpha 2 & $0.307^{* * *}$ & 0.000 \\
& $(0.013)$ & $(0.001)$ \\
& & \\
IV Delta & 0.022 & $0.218^{* * *}$ \\
& $(0.073)$ & $(0.034)$ \\
& & \\
IV Beta & -0.120 & $-0.346^{* * *}$ \\
& $(0.124)$ & $(0.023)$ \\
Male & & \\
& 0.025 & $0.010^{* * *}$ \\
Extreme Patience & $(0.017)$ & $(0.003)$ \\
& 0.011 & $0.078^{* * *}$ \\
Extreme Impatience & $(0.024)$ & $(0.004)$ \\
& -0.032 & $0.030^{* * *}$ \\
& $(0.025)$ & $(0.004)$ \\
\hline Mean DV & .505 & .871 \\
Cluster & 0.290 & 0.329 \\
Observations & 1343 & 1370 \\
\hline \hline
\end{tabular}

Robust standard errors reported, clustered on ID. Dependent variable in column heading. All specifications also include controls for Salary, Salary Squared, Age, Age Squared, Years of Tenure, Years of Tenure Squared, binary variables for Extreme Patience and Extreme Impatience, Work Location, Job Position, and Trust in Fed. Gov. as Employer. * $\mathrm{p}<0.10,{ }^{* *} \mathrm{p}<$ $0.05, * * * \mathrm{p}<0.01$. 
Table B.5: First Stage for Column (8), Table 1

\begin{tabular}{lccc}
\hline \hline & $(1)$ & $(2)$ & $(3)$ \\
& Alpha & Beta & Delta \\
\hline IV Alpha 1 & $0.307^{* * *}$ & -0.001 & 0.000 \\
& $(0.013)$ & $(0.001)$ & $(0.001)$ \\
& & & \\
IV Alpha 2 & $0.307^{* * *}$ & -0.001 & 0.000 \\
& $(0.013)$ & $(0.001)$ & $(0.001)$ \\
& & & \\
IV Beta & -0.052 & $-0.141^{* * *}$ & $-0.148^{* * *}$ \\
& $(0.053)$ & $(0.036)$ & $(0.009)$ \\
IV Delta & & & \\
& 0.043 & $-0.347^{* * *}$ & $0.278^{* * *}$ \\
& $(0.070)$ & $(0.026)$ & $(0.032)$ \\
Male & & & \\
& 0.026 & -0.007 & $0.012^{* * *}$ \\
& $(0.017)$ & $(0.005)$ & $(0.003)$ \\
Extreme Patience & & & \\
& 0.009 & $0.027^{* * *}$ & $0.073^{* * *}$ \\
& $(0.024)$ & $(0.006)$ & $(0.004)$ \\
Extreme Impatience & -0.029 & $-0.059^{* * *}$ & $0.040^{* * *}$ \\
& $(0.024)$ & $(0.009)$ & $(0.004)$ \\
\hline Mean DV & .505 & 1.006 & .871 \\
C-squared & 0.290 & 0.140 & 0.296 \\
Observations & 1343 & 1370 & 1370 \\
\hline \hline
\end{tabular}

Robust standard errors reported, clustered on ID. Dependent variable in column heading. All specifications also include controls for Salary, Salary Squared, Age, Age Squared, Years of Tenure, Years of Tenure Squared, binary variables for Extreme Patience and Extreme Impatience, Work Location, Job Position, and Trust in Fed. Gov. as Employer. ${ }^{*} \mathrm{p}<0.10,{ }^{* *} \mathrm{p}<$ $0.05, * * * \mathrm{p}<0.01$. 